\title{
Residual effect of BNI by Brachiaria humidicola pasture on nitrogen recovery and grain yield of subsequent maize
}

\author{
Hannes Karwat • Danilo Moreta • Jacobo Arango • \\ Jonathan Núñez • Idupulapati Rao • Álvaro Rincón • \\ Frank Rasche • Georg Cadisch
}

Received: 26 January 2017 / Accepted: 10 August 2017 /Published online: 12 September 2017

(C) The Author(s) 2017. This article is an open access publication

\begin{abstract}
Background and Aims The forage grass Brachiaria humidicola $(\mathrm{Bh})$ has been shown to reduce soil microbial nitrification. However, it is not known if biological nitrification inhibition (BNI) also has an effect on nitrogen $(\mathrm{N})$ cycling during cultivation of subsequent crops. Therefore, the objective of this study was to investigate the
\end{abstract}

Responsible Editor: Martin Weih.

Electronic supplementary material The online version of this article (https://doi.org/10.1007/s11104-017-3381-z) contains supplementary material, which is available to authorized users.

H. Karwat · F. Rasche $\cdot$ G. Cadisch $(\bowtie)$

Institute of Agricultural Sciences in the Tropics

(Hans-Ruthenberg-Institute), University of Hohenheim,

70593 Stuttgart, Germany

e-mail: georg.cadisch@uni-hohenheim.de

D. Moreta $\cdot$ J. Arango $\cdot$ J. Núñez $\cdot$ I. Rao

International Center for Tropical Agriculture (CIAT),

Headquarters and Regional Office for Latin America and the

Caribbean, Km 17 Recta Cali-Palmira, A.A. 6713, Cali, Colombia

Á. Rincón

Colombian Corporation for Agricultural Research (Corpoica), C.I.

La Libertad, 6709700 Villavicencio, Meta, Colombia

Present Address:

I. Rao

Plant Polymer Research Unit, National Center for Agricultural Utilization Research, Agricultural Research Service, United States Department of Agriculture, 1815 North University Street, Peoria, IL 61604, USA residual BNI effect of a converted long-term Bh pasture on subsequent maize (Zea mays L.) cropping, where a long-term maize monocrop field (M) served as control. Methods Four levels of $\mathrm{N}$ fertilizer rates $(0,60,120$ and $240 \mathrm{~kg} \mathrm{~N} \mathrm{ha}{ }^{-1}$ ) and synthetic nitrification inhibitor (dicyandiamide) treatments allowed for comparison of BNI effects, while ${ }^{15} \mathrm{~N}$ labelled micro-plots were used to trace the fate of applied fertilizer N. Soil was incubated to investigate $\mathrm{N}$ dynamics.

Results A significant maize yield increase after Bh was evident in the first year compared to the $\mathrm{M}$ treatment. The second cropping season showed an eased residual effect of the Bh pasture. Soil incubation studies suggested that nitrification was significantly lower in $\mathrm{Bh}$ soil but this BNI declined one year after pasture conversion. Plant $\mathrm{N}$ uptake was markedly greater under previous Bh compared with $\mathrm{M}$. The $\mathrm{N}$ balance of the ${ }^{15} \mathrm{~N}$ micro-plots revealed that $\mathrm{N}$ was derived mainly (68$86 \%$ ) from the mineralized soil organic $\mathrm{N}$ pool in $\mathrm{Bh}$ while plant fertilizer $\mathrm{N}$ recovery $(18-24 \%)$ was not enhanced.

Conclusions Applied N was strongly immobilized due to long-term root turnover effects, while a significant residual BNI effect from $\mathrm{Bh}$ prevented re-mineralized $\mathrm{N}$ from nitrification resulting in improved maize performance. However, a significant residual Bh BNI effect was evident for less than one year only.

Keywords Biological nitrification inhibition $\cdot \mathrm{N}$ use efficiency $\cdot \mathrm{N}$ recovery Soil incubation $\cdot$ Nitrate leaching $\cdot{ }^{15} \mathrm{~N}$ 


\section{Introduction}

Lost fertilizer nitrogen $(\mathrm{N})$ from agricultural systems harms the environment via increased nitrate $\left(\mathrm{NO}_{3}{ }^{-}\right)$ amounts in water-bodies and nitrous oxide $\left(\mathrm{N}_{2} \mathrm{O}\right)$ emissions to the atmosphere (Baligar et al. 2001). Nitrification is the microbial oxidation of ammonium $\left(\mathrm{NH}_{4}{ }^{+}\right)$to $\mathrm{NO}_{3}{ }^{-}$, whereas the latter mineral $\mathrm{N}$ form, due to its anionic charge, is very mobile in the mainly negative charged soil matrix compared to cationic $\mathrm{NH}_{4}{ }^{+}$. Denitrifying microbes use $\mathrm{NO}_{3}{ }^{-}$for their metabolism mainly under anaerobic conditions and contribute to $\mathrm{N}$ losses in gaseous forms. Natural grassland or forest systems generally have lower nitrification potentials compared with human made agricultural systems supplied with high $\mathrm{N}$ inputs that spur soil nitrification and consequently favor high $\mathrm{N}$ losses (Robertson and Groffman 2015).

Strategies to suppress nitrification after $\mathrm{N}$ fertilization could result in higher uptake of $\mathrm{N}$ in the form of $\mathrm{NH}_{4}{ }^{+}$ by crops and might be additionally beneficial for plants preferring $\mathrm{N}^{-\mathrm{NH}_{4}}{ }^{+}$(Boudsocq et al. 2012), while reducing $\mathrm{N}$ losses to the environment. Synthetic nitrification inhibitors (SNIs) like nitrapyrin, 3,4-dimethylpyrazole phosphate (DMPP) and dicyandiamide (DCD) were shown to inhibit the activity of soil nitrifiers, but persistence of their effectiveness depends strongly on environmental factors (Zerulla et al. 2001; Fillery 2007; Ruser and Schulz 2015). In addition, prices for SNIs are beyond the reach of smallholders that manage low input systems in tropical and subtropical regions.

Research evidence for inhibition of $\mathrm{NO}_{3}{ }^{-}$accumulation in a Colombian pasture soil under Brachiaria humidicola (Rendle) Schweick (Bh) was generated for the first time by Sylvester-Bradley et al. (1988). The development of a bioassay (Subbarao et al. 2006a) using the inhibitory action of $\mathrm{Bh}$ root exudates on recombinant Nitrosomonas europaea (Iizumi et al. 1998) subsequently allowed the detection of biological nitrification inhibition (BNI) in several tropical pasture grasses (Subbarao et al. 2007a). Using hydroponic systems, it was claimed that the exudation of BNI substances from roots of Bh is an active release of biological nitrification inhibitors that are triggered by the presence of $\mathrm{NH}_{4}{ }^{+}$(Subbarao et al. 2007b). These Bh exudates contained BNI active substances like methyl-p-coumarate and methyl ferulate, while the shoot tissue contained other very effective BNI substances such as linoleic acid (LA) and linolenic (LN) acid (Gopalakrishnan et al. 2009). Additionally, the cyclic diterpene brachialactone was suggested to be the main substance in root exudates of Bh that suppresses nitrification (Subbarao et al. 2009). Moreover, BNI exudation is favored by low $\mathrm{pH}$ (Subbarao et al. 2007b).

However, little is known about the turnover of such compounds in soils. First studies under controlled conditions by Subbarao et al. (2008) indicated that LA maintained $50 \%$ of its inhibitory effect in terms of $\mathrm{NO}_{3}{ }^{-}$ produced per $\mathrm{g}$ dry soil after 120 days, whereas the BNI effect of LN was stable until the end of the incubation period (4 months). Since it was observed that a major BNI effect in Bh pastures can be established within 3 years (Subbarao et al. 2009), it is also likely that next to the active release of BNI substances root decomposition could contribute to the accumulation of BNI products in soil. Consequently, such a mechanism could result in a steady release of BNI substances inhibiting microbial nitrification for a prolonged time. This would be advantageous over SNIs that are exposed to rapid leaching under high rainfall and temperature conditions. Furthermore Brachiaria grasses are known for their deep rooting systems (Fisher et al. 1994; Boddey et al. 1996; Rao 1998) that could release BNI substances and inhibit nitrification and denitrification also in deeper soil layers.

Not much is known about how long and to what extent the BNI effect in soil remains after removal of $\mathrm{Bh}$ pastures. Furthermore, most of these substances are apparently anionic (Subbarao et al. 2007b) and will not be fixed by predominantly negatively charged soil aggregates. Additionally, microbes may start decomposing BNI substances once released to the soil as observed for other organic root derived substances (Lynch and Whipps 1990). A BNI persistence is of major interest for arable systems that obtain substantial $\mathrm{N}$ inputs often associated with high $\mathrm{N}$ losses. Tropical natural grasslands used as pastures are not fertilized and pastures with introduced grasses are commonly only initially fertilized during establishment (Miles et al. 2004). However fertilization takes part when degraded pastures are converted to crop areas (Kluthcouski et al. 2004). For instance, intensive cropping systems like mono-cropped maize often have low nitrogen use efficiency (NUE) (Raun and Johnson 1999). This is evidenced by high unaccounted $\mathrm{N}$ losses of 52-73\% (Francis et al. 1993) in maize cropping systems via $\mathrm{NO}_{3}{ }^{-}$leaching and $\mathrm{N}_{2} \mathrm{O}$ emission (Hilton et al. 1994) under high rainfall conditions. Specifically, when plants are still young and the root system is still small $\mathrm{N}-\mathrm{NH}_{4}{ }^{+}$fertilizer is rapidly nitrified accelerating environmental problems (Schröder et al. 2000). 
To counteract these $\mathrm{N}$ losses, it could be speculated that pre-cropping of BNI plants contributes to inhibition of nitrification and consequently reduces $\mathrm{N}$ losses of applied fertilizer of subsequent cropping systems if the BNI active substances persist sufficiently long enough in soils. This is of great importance since Bh is one of the most exploited species planted in approximately 118 million hectares in Latin America (Miles et al. 2004). Potential benefits for subsequent crops in agro-pastoral rotation systems have been shown for upland rice after pasture (Sanz et al. 2004) although a possible contribution of BNI has not been established. The present study was conducted as part of a larger project on BNI (Rao et al. 2014). The first objective of this study was to test the residual BNI effect from a Bh pasture on subsequent maize crop performance in terms of grain yield, total $\mathrm{N}$ uptake and fertilizer $\mathrm{N}$ recovery. The second objective was to investigate the impact of residual BNI effect on soil $\mathrm{N}$ dynamics. Three hypotheses were tested: (I) A significant residual BNI effect is still present in the soil after removal of $\mathrm{Bh}$, but is diminished in the second maize crop season compared to the first year after pasture conversion. (II) Nitrification inhibition is reflected by lower $\mathrm{NO}_{3}{ }^{-}$ amounts, lower nitrous oxide emissions, lower $\mathrm{N}$ fertilizer losses and consequently by improved soil $\mathrm{N}$ recovery in converted soils. (III) The turnover of $\mathrm{Bh}$ pasture residues in the converted soils have a positive effect on $\mathrm{N}$ nutrition, NUE and improved maize grain yield.

\section{Materials and methods}

Field site and experimental set-up

The study location was established at the Corpoica La Libertad Research Center in the Piedmont (Andean foothills) region of the Llanos of Colombia ( $4^{\circ} 03^{\prime} 46^{\prime \prime}$ $\left.\mathrm{N}, 73^{\circ} 27^{\prime} 47^{\prime \prime} \mathrm{W}\right)$. Mean annual rainfall is about $3685 \mathrm{~mm}$ with an average temperature of $21.4{ }^{\circ} \mathrm{C}$ at an elevation of $338 \mathrm{~m}$ above sea level.

The experiment included two fields (each $0.5 \mathrm{ha}$ ) in close vicinity ( $\sim 2.3 \mathrm{~km}$ away). The first one, a 15 yearsold productive Brachiaria humidicola (Rendle) Schweick cultivar Tully (CIAT 679) pasture (Bh) with high BNI potential (Subbarao et al. 2007a, 2009) was used to establish a maize (Zea mays L.) cropping field to test the residual BNI effect. As non BNI control field, a nearby cropped area, where maize $(\mathrm{M})$ was grown as monocrop for the last 15 years was chosen. Fields were chisel plowed 2 times on May 25, 2013 and sprayed with glyphosate afterwards to impede regrowth of $\mathrm{Bh}$ and weeds. Dolomitic lime was applied at a rate of $2 \mathrm{t}$ $\mathrm{ha}^{-1}$ to the field of the previous pasture whereas the maize field received $0.5 \mathrm{t} \mathrm{ha}^{-1}$ of lime. The different amounts of chalk were applied to align the different $\mathrm{pH}$ values of the two field sites (Table 1).

Each field site was split into 3 blocks with each block containing 4 main plots $(20 \times 20 \mathrm{~m})$ that received different $\mathrm{N}$ fertilizer rates $\left(0,60,120\right.$ and $\left.240 \mathrm{~kg} \mathrm{~N}^{-1}\right)$. A subplot was nested within the main plot with a size of $4.8 \times 2.25 \mathrm{~m}\left(10.8 \mathrm{~m}^{2}\right)$ consisting of a synthetic nitrification inhibitor (DCD, dicyandiamide) treatment for the 3 levels of $\mathrm{N}\left(60,120\right.$ and $\left.240 \mathrm{~kg} \mathrm{~N} \mathrm{ha}^{-1}\right)$. Basal fertilization included (per ha) $36 \mathrm{~kg} \mathrm{~N}$ applied in the form of diammonium phosphate (DAP), $75 \mathrm{~kg}$ potassium $(\mathrm{K})$ and 40 (50 in 2014) $\mathrm{kg}$ phosphorus (P) combined with $30 \mathrm{~kg}$ Boronzinco® $(4.5 \mathrm{~kg} \mathrm{Zn}, 0.15 \mathrm{~kg} \mathrm{Cu}, 0.75 \mathrm{~kg} \mathrm{~B}$, $1.8 \mathrm{~kg} \mathrm{~S})$ and $100 \mathrm{~kg}$ Delfoscamag® $\left(3.3 \mathrm{~kg} \mathrm{P}_{2} \mathrm{O}_{5}, 13 \mathrm{~kg}\right.$ $\mathrm{MgO}, 30 \mathrm{~kg} \mathrm{CaO}, 8 \mathrm{~kg} \mathrm{~S}$ ). Control plots (" $0 \mathrm{~N}$ ") were not supplied with $\mathrm{N}$ but with all other mentioned elements. For the second and third N split dressing in 2013, N was supplied in the form of urea equally at 15 (17 in 2014) days after sowing (DAS) and 41 DAS, respectively. DCD was applied to respective sub-plots at the second and third $\mathrm{N}$ split application in both seasons with a total fertilizer $\mathrm{N}$ contribution rate of $20 \%$ DCD-N.

Maize was cropped in the last months (12 July 2013 and 27 June 2014) of the rainy seasons (Fig. 1). In 2013, a maize hybrid (Pioneer $30 \mathrm{~K} 73$ ) was sown in both fields using a planting density of 50,000 plants $\mathrm{ha}^{-1}$. In the second season (2014) a maize hybrid (Monsanto Dekalb 1596) with improved tolerance to fungal infection was chosen for both sites and sown at the recommended 60,000 plants $\mathrm{ha}^{-1}$. Due to different maturity of the two hybrids, maize cobs in the first season (2013) were harvested at 120 DAS, while in the second season (2014) they were harvested at 138 DAS. Grain yields were extrapolated based on the number of rows ha ${ }^{-1}$. Agronomic $\mathrm{N}$ use efficiency (ANUE) was calculated by dividing the applied fertilizer $\mathrm{N}$ amounts by $\mathrm{N}$ in maize grain yields.

\section{Mineral N determination}

Mineral $\mathrm{N}\left(\mathrm{N}_{\min }\right)$ determination was done in 2013 at 41 DAS (before third $\mathrm{N}$ split application) and at 82 DAS. In 2014, mineral $\mathrm{N}$ was measured before second and after third $\mathrm{N}$ dressing. Soil $\mathrm{N}_{\min }$ was extracted at the field site 
Table 1 Topsoil chemical characteristics of the two field sites at Corpoica - La Libertad Research Center in the Andean foothills of Colombia

\begin{tabular}{|c|c|c|c|c|c|c|c|c|c|c|c|c|}
\hline Year & Field site & $\begin{array}{l}\text { Depth } \\
(\mathrm{cm})\end{array}$ & $\mathrm{pH}$ & $\begin{array}{l}\mathrm{OM} \\
(\%)\end{array}$ & $\begin{array}{l}\mathrm{N} \\
(\%)\end{array}$ & $\mathrm{C}: \mathrm{N}$ & $\begin{array}{l}\text { P Bray II } \\
\left(\mathrm{mg} \mathrm{kg}^{-1}\right)\end{array}$ & CEC & $\begin{array}{l}\mathrm{Al}^{2+} \\
(\mathrm{mm}\end{array}$ & $\begin{array}{l}\mathrm{Ca}^{2+} \\
\left.\mathrm{g}^{-1}\right)\end{array}$ & $\mathrm{Mg}^{2+}$ & $\mathrm{K}^{+}$ \\
\hline \multirow[t]{2}{*}{2013} & Long-term $B$. humidicola & $0-20$ & 5.2 & 4.0 & 0.15 & 14.7 & 2.5 & 32.2 & 8.2 & 15.2 & 7.3 & 1.5 \\
\hline & Long-term Zea mays & $0-20$ & 5.4 & 3.0 & 0.11 & 12.4 & 16.3 & 28.9 & 8.2 & 13.1 & 6.0 & 1.2 \\
\hline \multirow[t]{2}{*}{2014} & Long-term $B$. humidicola & $0-20$ & 5.5 & 3.8 & 0.17 & 10.3 & 3.0 & 72.2 & 0.9 & 16.9 & 7.8 & 2.2 \\
\hline & Long-term Zea mays & $0-20$ & 5.5 & 2.5 & 0.11 & 12.8 & 28.4 & 60.0 & 0.9 & 11.5 & 5.6 & 1.8 \\
\hline
\end{tabular}

Soil samples were taken after lime application and before maize sowing in both years respectively

with $1 \mathrm{M} \mathrm{KCl}$. At each sampling date, 8 samples were taken randomly with an auger from the topsoil layer (0$20 \mathrm{~cm}$ ) from each main and DCD subplot from the Bh and $\mathrm{M}$ fields (in 2014 only in the most contrasting $\mathrm{N}$ treatment plots, 0 and $240 \mathrm{~N}$ ). Two representative subsamples of $20 \mathrm{~g}$ fresh soil were taken. One sub-sample was used for determination of the soil dry matter by the gravimetric method, whereas another sub-sample was mixed in plastic bottles with $200 \mathrm{ml}$ of $\mathrm{KCl}$ solution for $\mathrm{N}_{\text {min }}$ determination. The bottles were shaken intermittently by hand for about half an hour and filtered through Whatman Grade 2 filter paper. Filtered extracts kept at $4{ }^{\circ} \mathrm{C}$. $\mathrm{NO}_{3}{ }^{-}$were measured in yellow ionized form derived from alkalization with sodium salicylate and $\mathrm{NH}_{4}{ }^{+}$as green ammonium salicylate complex with a Synergy Ht ultraviolet spectrophotometer and analyzed with Gen5' ${ }^{\text {TM }}$ Data Collection and Analysis Software $\left(\right.$ BioTek $\left.^{\mathrm{TM}}\right)$.

\section{Soil incubations}

Soil was collected from the fields for incubation studies conducted under controlled conditions. This method was chosen to determine differences in nitrification activity among the field sites (I), and secondly to test the efficiency of DCD (II) that was used as an alternative for having a non-BNI control in the trial. Topsoil $(0-20 \mathrm{~cm})$ was collected from main plots before sowing in both seasons and air dried for $48 \mathrm{~h}$ and sieved $(2 \mathrm{~mm}$ mesh size) and visible root residues and small stones were removed. Afterwards, $5 \mathrm{~g}$ of soil were filled in small glass flasks followed by application of $1.5 \mathrm{ml}$ ammonium sulfate $\left(\left(\mathrm{NH}_{4}\right)_{2} \mathrm{SO}_{4}\right)$ solution as substrate for nitrifiers. The $\mathrm{N}$ concentration applied to the flask was $226.4 \mathrm{mg} \mathrm{N}^{-\mathrm{NH}_{4}}{ }^{+} \mathrm{kg}$ dry soil ${ }^{-1}$. DCD was diluted with the $\mathrm{NH}_{4}{ }^{+}$solution at $20 \%$ of DCD-N contribution of the total $\mathrm{N}$ applied to the incubated soil (according to pre-

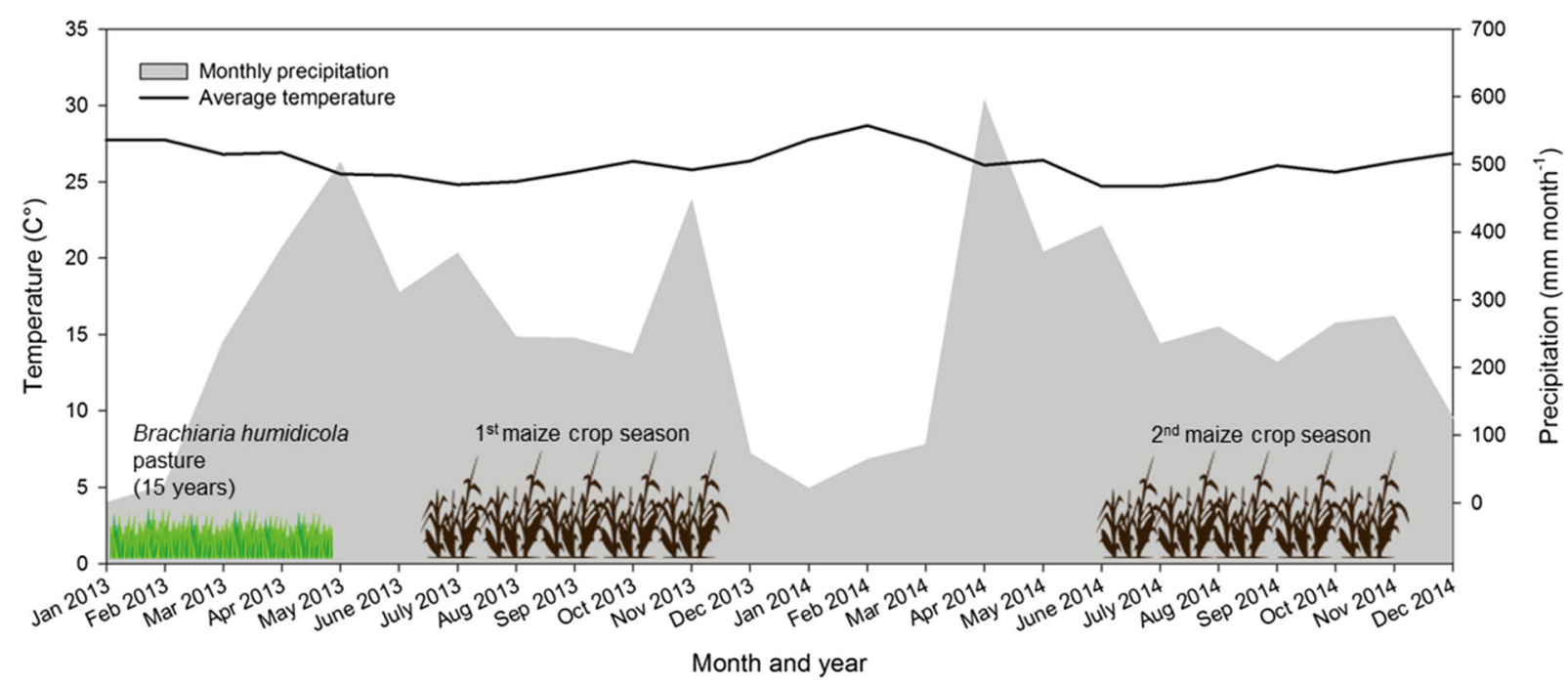

Fig. 1 Distribution of monthly precipitation $\left(\mathrm{mm} \mathrm{month}^{-1}\right)$ and average temperature $\left(\mathrm{C}^{\circ}\right)$ during the years 2013 and 2014 at Corpoica La Libertad Research Center with indication of the
Brachiaria humidicola CIAT 679 long-term pasture (Bh treatment) and the duration of the 2 maize crop experiments in the rainy seasons 


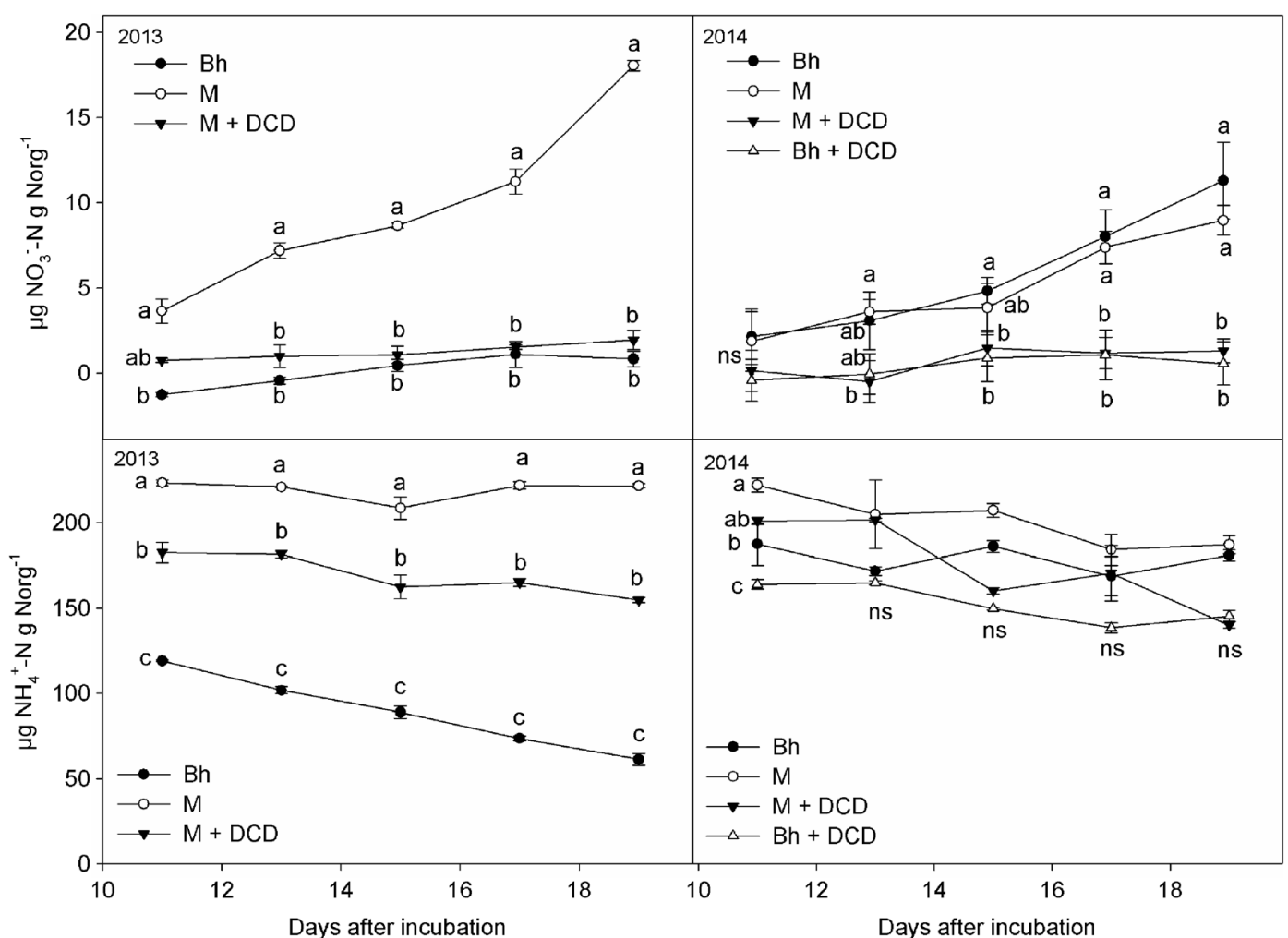

Fig. 2 Mineral $\mathrm{N}$ dynamics in the incubated soils. Net nitrification activity expressed as $\mu \mathrm{g} \mathrm{N}-\mathrm{NO}_{3}{ }^{-} \mathrm{g} \mathrm{N}$ org (upper graphs) and net $\mathrm{NH}_{4}{ }^{+}$mineralization activity in $\mu \mathrm{g} \mathrm{N}-\mathrm{NH}_{4}{ }^{+} \mathrm{g} \mathrm{N}_{\text {org }}$ (lower graphs) in incubated soils 11 to 19 days after initiation. Soil samples were taken before maize sowing in 2013 and 2014. Field sites differed in their preceding land use $(\mathrm{Bh}=$ long-term Brachiaria humidicola

tests, data not shown). Flasks were sealed with parafilm that contained 2 holes for aeration and incubated at $25^{\circ} \mathrm{C}$ in the dark for $11,13,15,17$ and 19 days when soil $\mathrm{N}_{\text {min }}$ was extracted with $50 \mathrm{ml} 1 \mathrm{M} \mathrm{KCl}$. Nitrification in soil was expressed as net increase (deviation from basal $\mathrm{N}$ ) of $\mu \mathrm{g} \mathrm{N}-\mathrm{NO}_{3}{ }^{-}$g organic $\mathrm{N}^{-1}\left(\mathrm{~N}_{\text {org }}{ }^{-1}=\right.$ total $\left.\mathrm{N}-\mathrm{N}_{\min }\right)$, whereas apparent net mineralization was calculated as $\mu \mathrm{g} \mathrm{N}-\mathrm{NH}_{4}^{+} \mathrm{g} \mathrm{N}_{\text {org }}^{-1}$ over time. Total $\mathrm{N}$ was measured with an isotope ratio mass spectrometer (IRMS) as for other soil samples explained below.

\section{${ }^{15} \mathrm{~N}$ micro-plots}

For the $\mathrm{N}$ treatments $60 \mathrm{~N}$ (only 2013) and $120 \mathrm{~N}$ (2013 and 2014), ${ }^{15} \mathrm{~N}$ labeled $\mathrm{N}$ fertilizer was used to trace the fate of applied $\mathrm{N}$ and to determine ${ }^{15} \mathrm{~N}$ recovery in different soil layers and in maize plant tissue. Micro-plots were pasture, $\mathrm{M}=$ Zea mays mono-crop). DCD was added to $\mathrm{M}$ soil as synthetic nitrification inhibition control. Error bars indicate standard error (SE) of the mean. Values with same letters at equal sampling points are not statistically significantly different for least squares means $(\alpha=0.05)$

set up within the respective main plots of the $\mathrm{N}$ treatments mentioned above. Aluminum sheets were riveted together to a frame that was penetrated into the soil to a depth of $50 \mathrm{~cm}$ below the soil surface. Micro-plots had a size of $1.2 \mathrm{~m}^{2}(2 \mathrm{~m} \times 0.6 \mathrm{~m})$ in 2013 and $1.0 \mathrm{~m}^{2}(2 \mathrm{~m} \times 0.5 \mathrm{~m})$ in 2014 (due to higher planting density) and included 6 maize plants. 10.3883 atom $\%{ }^{15} \mathrm{~N}$ enriched ammonium sulfate $\left({ }^{15} \mathrm{NH}_{4}\right)_{2} \mathrm{SO}_{4}$ (Sigma-Aldrich ${ }^{\circledR}$ ) was used to prepare the applied nutrient solution that was sprayed with a hand pump on the soil surface. Two liters of the corresponding $\mathrm{N}$ solution were applied at sowing, 16 DAS and 41 DAS in 2013 according to the $\mathrm{N}$ rates of the respective main plots. Second and third N dressing date in 2014 were changed to 25 DAS and 46 DAS due to practical workload. As control to the $120 \mathrm{~N}$ micro-plots, DCD was mixed with $\left({ }^{15} \mathrm{NH}_{4}\right)_{2} \mathrm{SO}_{4}$ and conventional $\left(\mathrm{NH}_{4}\right)_{2} \mathrm{SO}_{4}$ and applied to corresponding DCD micro-plots. 


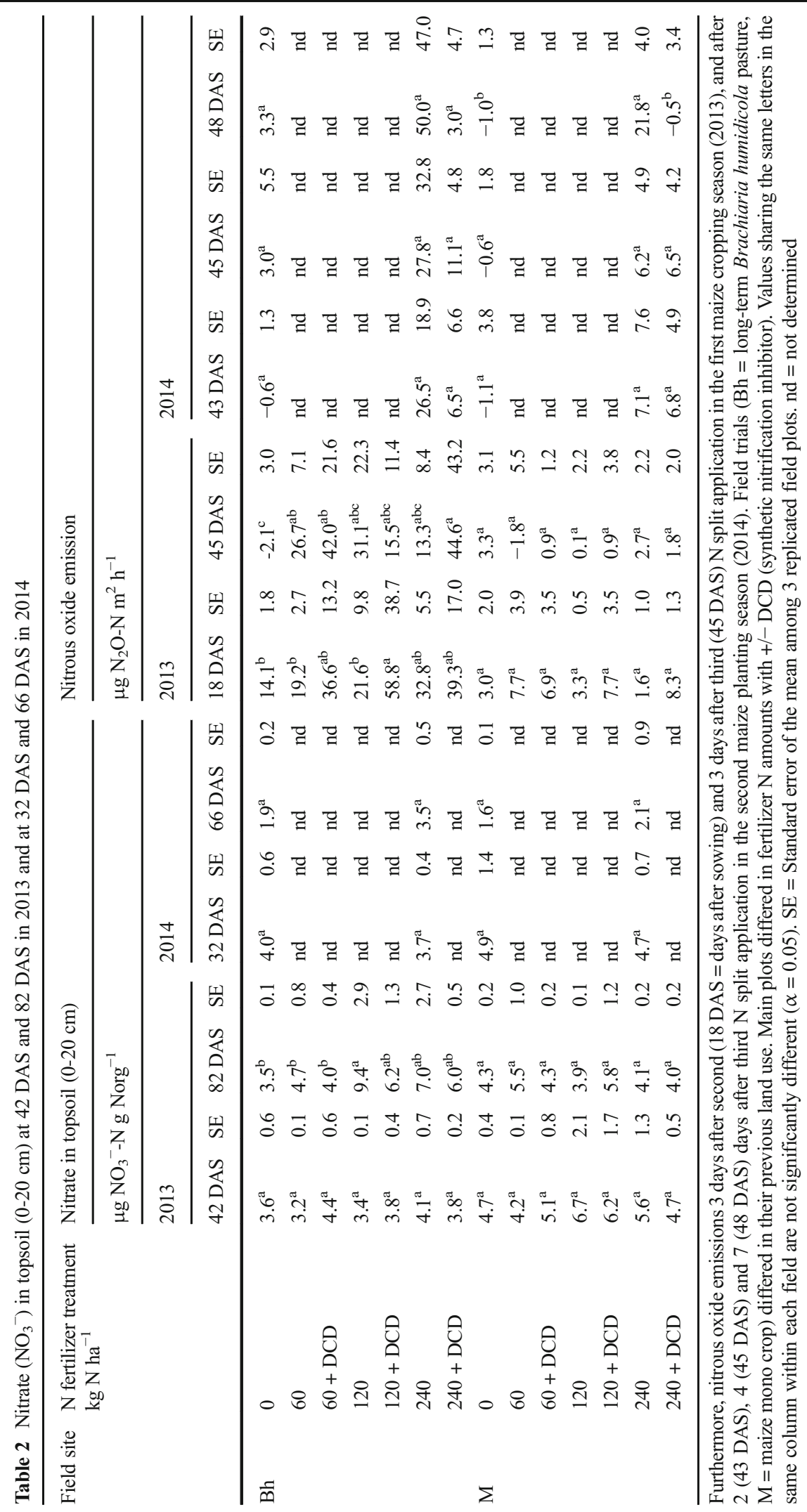




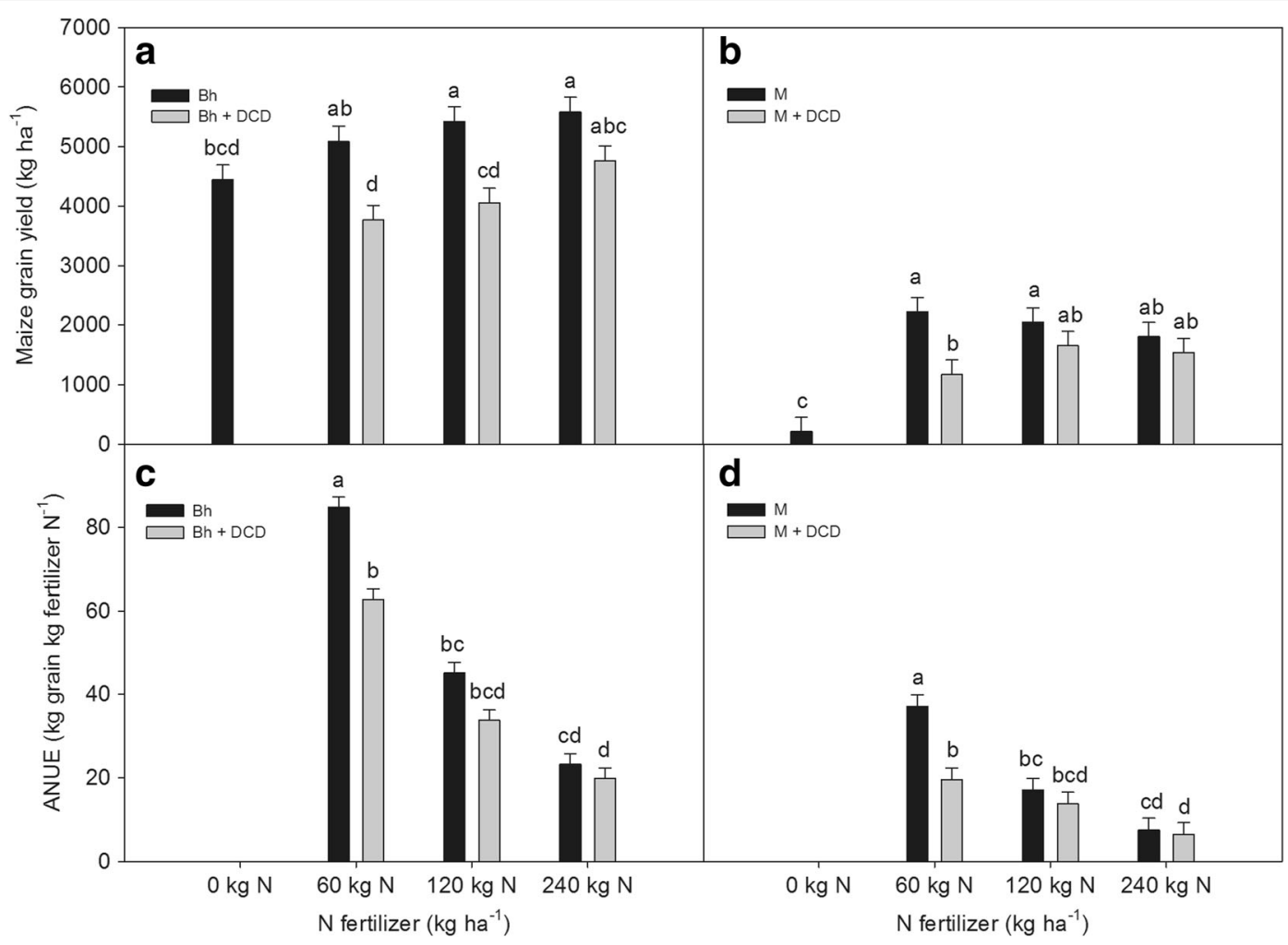

Fig. 3 Maize grain yields $\left(\mathrm{kg} \mathrm{ha}^{-1}\right)$ of the first season (2013) for $\mathrm{Bh}$ (a) and $\mathrm{M}$ (b). Agronomic nitrogen use efficiency (ANUE) (grain yield in $\mathrm{kg} \mathrm{ha}^{-1}$ per $\mathrm{kg}$ of applied $\mathrm{N}$ ) of the first cropping season (2013) for $\mathrm{Bh}$ (c) and $\mathrm{M}$ (d). Fields differed in their preceding land use $(\mathrm{Bh}=$ long-term Brachiaria humidicola pasture, $\mathrm{M}=$ Zea mays mono-crop). Each field site included four different $\mathrm{N}$ fertilization treatments from 0 to $240 \mathrm{~kg} \mathrm{~N} \mathrm{ha}^{-1}$. Data

Maize and soil harvest in ${ }^{15} \mathrm{~N}$ micro-plots

All plants from the micro-plots were harvested at the same time after sowing in the respective seasons (at 120 DAS in 2013 and at 138 DAS in 2014). Samples were oven dried at $60{ }^{\circ} \mathrm{C}$ for 7 days, then separated into grains, spindle, shoot, leaves and roots and shredded separately. Plant materials were ball-milled and an amount of exactly measured 3-4 mg of the low $\mathrm{N}$ containing tissues (stems, roots, leaves) was filled into tin capsules (5 × $9 \mathrm{~mm}$ HEKAtech GmbH, Germany), while $2-3 \mathrm{mg}$ of the ground maize grains were used for ${ }^{15} \mathrm{~N}$ determination. For the calculation of the ${ }^{15} \mathrm{~N}$ excess in the maize tissue, the background signal of nonenriched maize plant samples of the main and DCD subplots were measured.

Soil samples were taken right after harvest of the maize plants from the micro-plots. For estimation of soil ${ }^{15} \mathrm{~N}$ recovery, firstly the topsoil layer $0-10$ and 10 are mean values calculated from three randomized field plots. Additionally a synthetic nitrification inhibitor (+ DCD) was used as control. Error bars indicate standard error calculated by the means of the whole sample size within the same field. Values with same letters within each graph are not statistically significantly different for least squares means $(\alpha=0.05)$

$20 \mathrm{~cm}$ were removed from each of the micro-plots and placed separately on plastic sheets and homogenized and sub-samples were taken. Afterwards, 6 cores were taken with an auger for the respective soil layers 20-40, 40-60, 60-100 $\mathrm{cm}$ and sub-cores mixed to receive two samples per layer per micro-plot. To calculate the natural ${ }^{15} \mathrm{~N}$ enrichment of the soil, corresponding samples were taken with an auger from the main plots at the same soil layers. All soil samples were oven dried $\left(40{ }^{\circ} \mathrm{C}\right)$, homogenized, ground with a porcelain mortar and ball-milled. Furthermore, a set of intact cores of the respective main plots were taken for determination of bulk density and texture analysis according to the method of Zamudio et al. (2006).

\footnotetext{
${ }^{15} \mathrm{~N}$, total $\mathrm{N}$ analysis and calculation
}

Samples were analyzed for total $\mathrm{N}$ and ${ }^{15} \mathrm{~N}$ by using a Euro Elemental analyzer coupled to a Finnigan Delta 


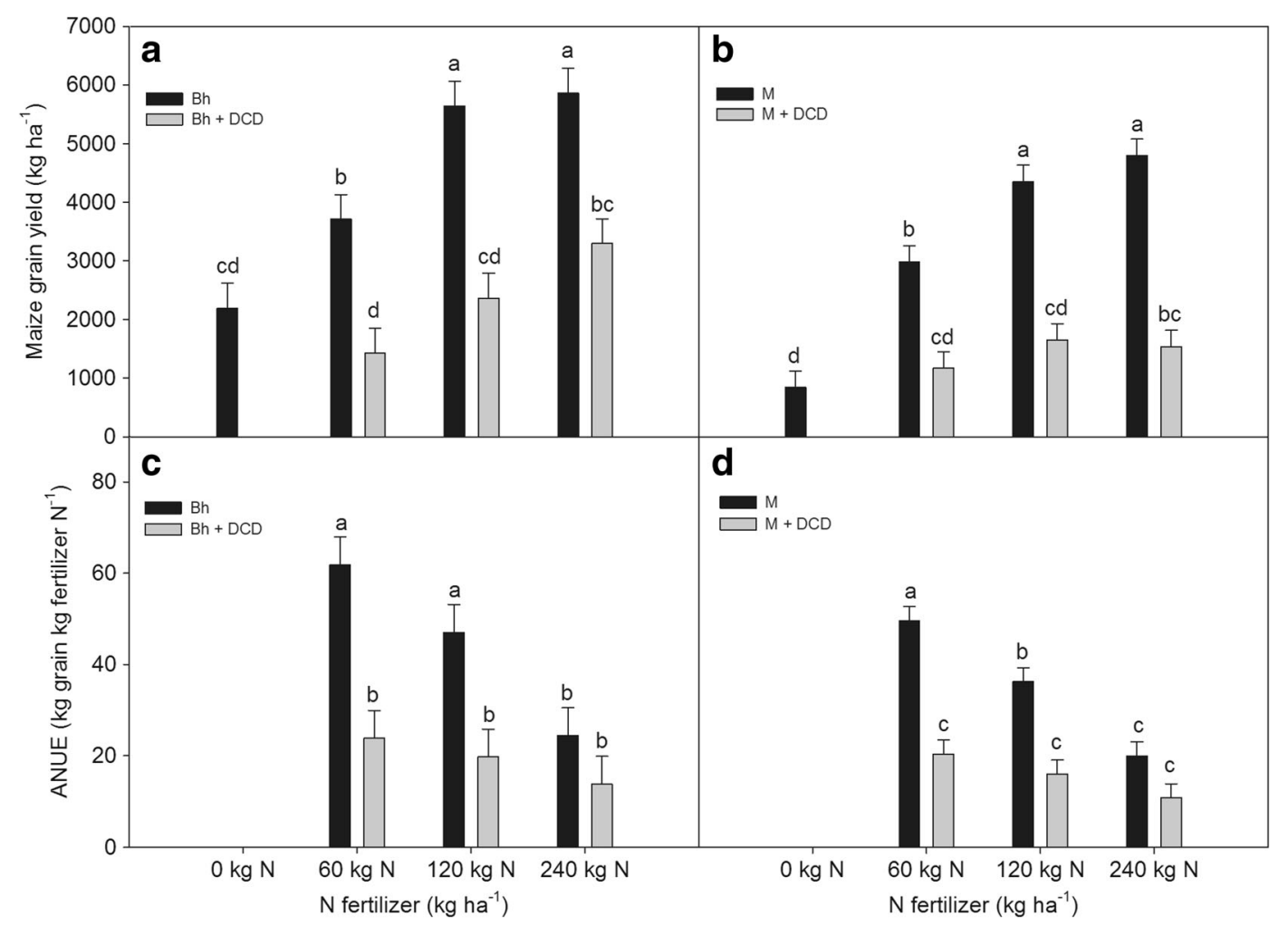

Fig. 4 Maize grain yields $\left(\mathrm{kg} \mathrm{ha}^{-1}\right)$ of the second season (2014) for Bh (a) and M (b). Agronomic nitrogen use efficiency (ANUE) (grain yield in $\mathrm{kg} \mathrm{ha}^{-1}$ per $\mathrm{kg}$ of applied $\mathrm{N}$ ) of the second cropping season (2014) for $\mathrm{Bh}$ (c) and $\mathrm{M}$ (d). Fields differed in their preceding land use $(\mathrm{Bh}=$ long-term Brachiaria humidicola pasture, $\mathrm{M}=$ Zea mays mono-crop). Each field site included four different $\mathrm{N}$ fertilization treatments from 0 to $240 \mathrm{~kg} \mathrm{~N}$ ha $^{-1}$. Data

are mean values calculated from three randomized field plots. Additionally a synthetic nitrification inhibitor (+ DCD) was used as control. Error bars indicate standard error calculated by the means of the whole sample size within the same field. Values with same letters within each graph are not statistically significantly different for least squares means ( $\alpha=0.05$ )

continuous-flow IRMS (Thermo Scientific, Bremen, Germany). The amount of the sampled material per capsule was calculated and adjusted to reach the optimal $\mathrm{N}$ target amount of about $50 \mu \mathrm{g} \mathrm{N}$ per sample. Yield and $\mathrm{N}$ recovery calculation were carried out following IAEA (2001) guidelines.

Maize yield for respective tissues was calculated according to the equation:

$$
\begin{aligned}
D M \text { yield }(\mathrm{kg} / \mathrm{ha})= & F W(\mathrm{~kg}) \\
& \times \frac{10000\left(\mathrm{~m}^{2} / \mathrm{ha}\right)}{\text { area harvested }\left(\mathrm{m}^{2}\right)} \\
& \times \frac{S D W(\mathrm{~kg})}{S F W(\mathrm{~kg})}
\end{aligned}
$$

Where DM refers to dry matter and FW to fresh weight per area harvested. SDW and SFW correspond

to dry weight and fresh weight of a sub-sample, respectively.

$\mathrm{N}$ yield for maize plants was estimated as:

$$
N \text { yield }\left(\mathrm{g} / \mathrm{m}^{2}\right)=\frac{D M \text { yield }\left(\mathrm{g} / \mathrm{m}^{2}\right) \times N(\%)}{100}
$$

Where $\%$ Ndff corresponds to ' $\mathrm{N}$ derived from the fertilizer' 


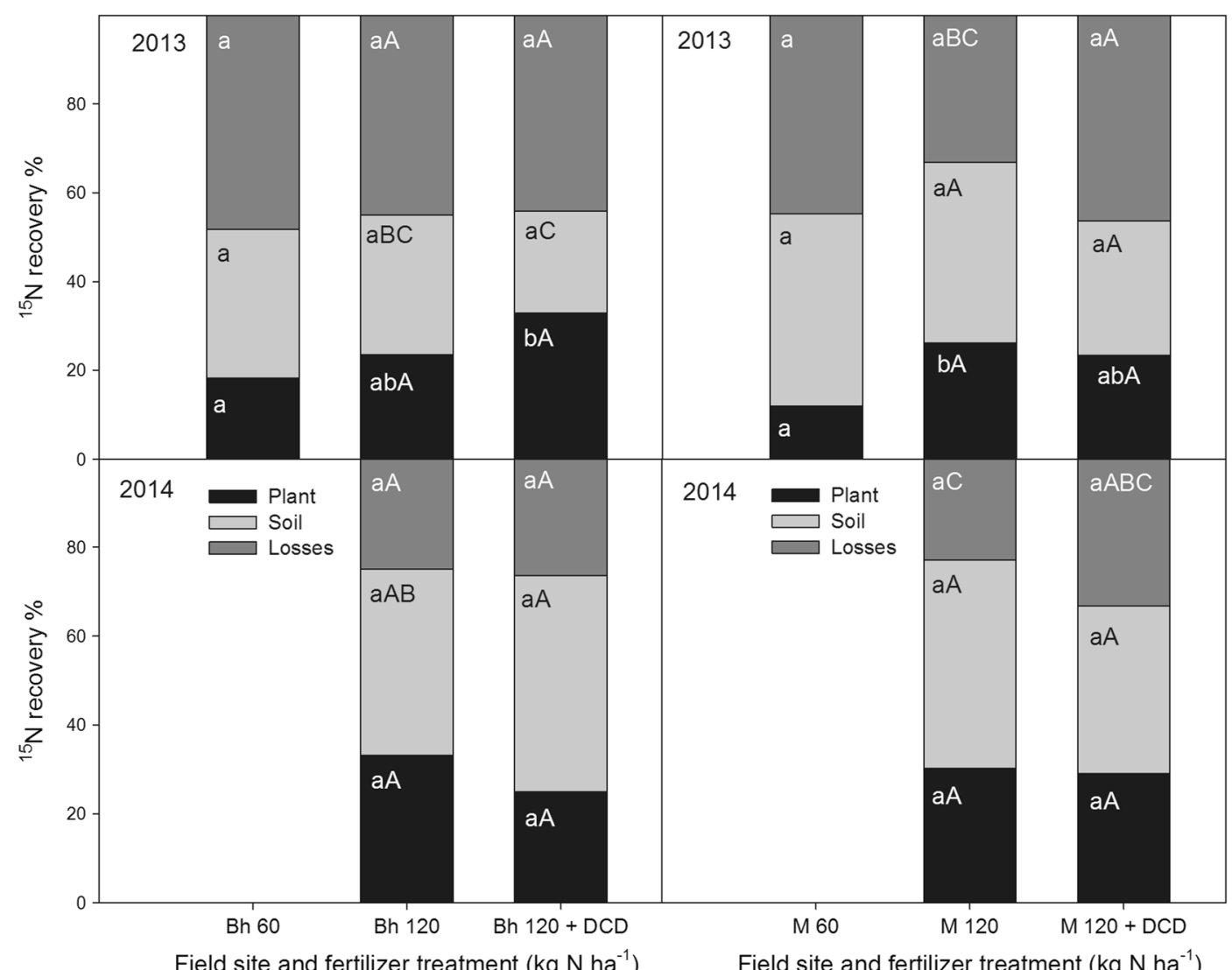

Fig. 5 Percentage of recovered ${ }^{15} \mathrm{~N}$ labeled $\mathrm{N}$ fertilizer in maize plants, soil profile $(0-60 \mathrm{~cm})$ and unaccounted $\mathrm{N}$ losses in ${ }^{15} \mathrm{~N}$ micro-plots during two maize cropping seasons (2013 and 2014). Micro-plots have been installed in two field sites differing in terms of the previous land use $(\mathrm{Bh}=$ long-term Brachiaria humidicola pasture, $\mathrm{M}=$ Zea mays mono-crop system). Plant and soil samples

$\%$ Ndff $=\frac{{ }^{15} \mathrm{~N} \text { atom } \% \text { excess in sample }}{{ }^{15} \mathrm{~N} \text { atom } \% \text { excess in fertilizer }} \times 100$

Fertilizer $\mathrm{N}$ recovery in maize plants or soil samples was calculated according to

\footnotetext{
${ }^{15} \mathrm{~N}$ recovery $\%=\frac{{ }^{15} \mathrm{~N} \text { excess amount sample }(g)}{{ }^{15} \mathrm{~N} \text { excess applied }(g)} \times 100$
}

were taken at 120 days after sowing (DAS). Values with same lowercase letters within the same site and year, and within similar colored bars (plant/soil/losses) are not statistically significantly different $(\alpha=0.05)$. Same uppercase letters indicate no statistically significant difference within the same site and bars of same color among the two field seasons (2013 and 2014)

${ }^{15} \mathrm{~N}$ excess amount sample $(g)$

$$
=\frac{N \text { amount sample }(g) \times{ }^{15} N \text { atom excess sample }}{100}
$$

${ }^{15} N$ excess applied $(g)=\frac{N \text { amount applied }(g) \times{ }^{15} N \text { atom excess fertilizer }}{100}$

${ }^{15} \mathrm{~N}$ atom excess sample

$$
={ }^{15} \mathrm{~N} \text { atom } \% \text { sample }-{ }^{15} \mathrm{~N} \text { atom } \% \text { background }
$$

${ }^{15} \mathrm{~N}$ atom\% background was measured in maize plants or soil samples taken from the main plots where the respective micro-plots were installed. 
Fig. 6 Percentage of recovered ${ }^{15} \mathrm{~N}$ labeled $\mathrm{N}$ fertilizer in 5 different soil layers of the soil profile in the first (2013) and second (2014) season at 120 days after sowing (DAS), respectively. Due to stones samples from 60 to $100 \mathrm{~cm}$ could not always be taken. Soil samples were collected from ${ }^{15} \mathrm{~N}$ micro-plots installed in main plots of different fertilizer $\mathrm{N}$ rates: $60 \mathrm{~kg} \mathrm{~N}^{-1}$, $120 \mathrm{~kg} \mathrm{~N} \mathrm{ha}^{-1}$ and $120 \mathrm{~kg} \mathrm{~N}$ $\mathrm{ha}^{-1}+$ DCD. Micro-plots have been installed in two field sites differing in terms of the previous land use $(\mathrm{Bh}=$ long-term Brachiaria humidicola pasture, $\mathrm{M}=$ Zea mays mono-crop system). Error bars indicate standard error of means of three samples taken from three randomized micro-plots

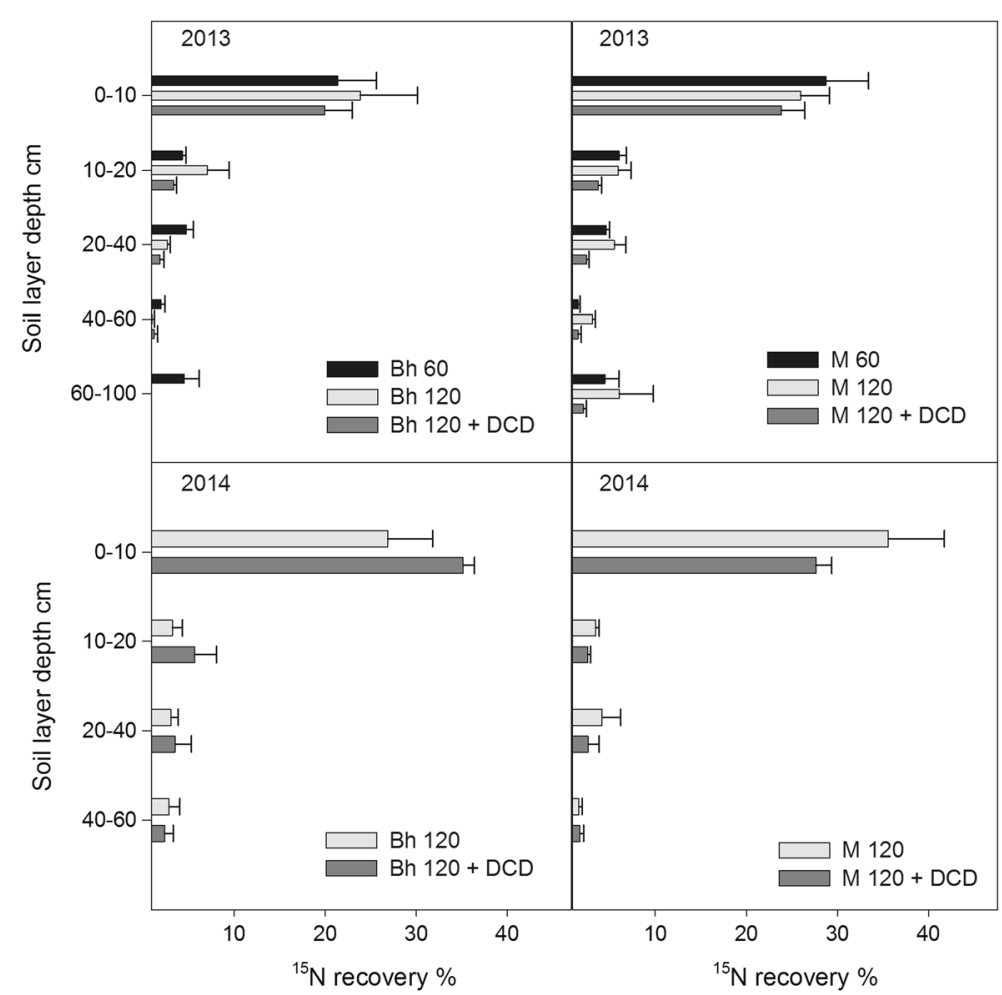

Nitrous oxide emission measurements

Static rings with an inner diameter of $16 \mathrm{~cm}$ (2013) and $21 \mathrm{~cm}$ (2014) were installed in all main and sub-plots at the two fields $\mathrm{M}$ and $\mathrm{Bh}$. For gas sampling, a chamber (volume $3901 \mathrm{~cm}^{3}$ in 2013, $6927 \mathrm{~cm}^{3}$ in 2014) was placed on the rings and sealed with a rubber band. A thermometer was installed through a sealed hole inside
Table 3 Summary of maize plant $\mathrm{N}$ recovery $(\%)$, plant $\mathrm{N}$ yield $\mathrm{kg} \mathrm{N} \mathrm{ha}{ }^{-1}$, plant $\mathrm{N}$ derived from applied $\mathrm{N}$ fertilizer $\left(\mathrm{kg} \mathrm{N}_{\mathrm{ha}}{ }^{-1}\right)$ and from soil in ${ }^{15} \mathrm{~N}$ micro-plots for the two field sites $\mathrm{M}$ and $\mathrm{Bh}$
$(\mathrm{M}=$ maize mono crop, $\mathrm{Bh}=$ long-term Brachiaria humidicola pasture) for both maize cropping seasons (2013 and 2014)

\begin{tabular}{|c|c|c|c|c|c|c|c|c|c|c|}
\hline \multirow[t]{2}{*}{ Field } & \multirow[t]{2}{*}{ Year } & \multirow{2}{*}{$\begin{array}{l}\mathrm{N} \text { treatment } \\
\mathrm{kg} \mathrm{N} \mathrm{ha}{ }^{-1}\end{array}$} & \multicolumn{2}{|c|}{ Plant $\mathrm{N}$ recovery } & \multicolumn{2}{|c|}{ Total plant $\mathrm{N}$ yield } & \multicolumn{2}{|c|}{$\mathrm{N}$ from fertilizer } & \multicolumn{2}{|l|}{$\mathrm{N}$ from soil } \\
\hline & & & $\%$ & $\mathrm{SE}$ & $\mathrm{kg} \mathrm{N} \mathrm{ha}^{-1}$ & SE & $\mathrm{kg} \mathrm{N} \mathrm{ha}^{-1}$ & SE & $\mathrm{kg} \mathrm{N} \mathrm{ha}^{-1}$ & $\mathrm{SE}$ \\
\hline \multirow[t]{5}{*}{$\mathrm{Bh}$} & \multirow[t]{3}{*}{2013} & $60 \mathrm{~N}$ & $18.2^{\mathrm{bA}}$ & 2.7 & $80.2^{\mathrm{aA}}$ & 11 & $10.9^{\mathrm{cA}}$ & 2.7 & $69.2^{\mathrm{aA}}$ & 7.9 \\
\hline & & $120 \mathrm{~N}$ & $23.6^{\mathrm{abA}}$ & 2.7 & $88.8^{\mathrm{aA}}$ & 11 & $28.3^{\mathrm{bA}}$ & 2.7 & $60.5^{\mathrm{aA}}$ & 7.9 \\
\hline & & $120 \mathrm{~N}+\mathrm{DCD}$ & $32.9^{\mathrm{aA}}$ & 2.7 & $95.2^{\mathrm{aA}}$ & 11 & $39.5^{\mathrm{aA}}$ & 2.7 & $55.8^{\mathrm{bA}}$ & 7.9 \\
\hline & \multirow[t]{2}{*}{2014} & $120 \mathrm{~N}$ & $33.1^{\mathrm{aA}}$ & 6.6 & $89.1^{\mathrm{aA}}$ & 18.2 & $34.1^{\mathrm{aA}}$ & 10.6 & $55.0^{\mathrm{aA}}$ & 8.2 \\
\hline & & $120 \mathrm{~N}+\mathrm{DCD}$ & $24.9^{\mathrm{aA}}$ & 6.6 & $86.2^{\mathrm{aA}}$ & 18.2 & $48.6^{\mathrm{aA}}$ & 10.6 & $37.6^{\mathrm{aA}}$ & 8.2 \\
\hline \multirow[t]{5}{*}{ M } & \multirow[t]{3}{*}{2013} & $60 \mathrm{~N}$ & $12.0^{\mathrm{bB}}$ & 3.5 & $23.0^{\mathrm{aC}}$ & 6.9 & $7.18^{\mathrm{bB}}$ & 4.1 & $15.8^{\mathrm{aB}}$ & 3.9 \\
\hline & & $120 \mathrm{~N}$ & $26.2^{\mathrm{aA}}$ & 3.5 & $45.2^{\mathrm{aB}}$ & 6.9 & $31.4^{\mathrm{aA}}$ & 4.1 & $13.9^{\mathrm{aB}}$ & 3.9 \\
\hline & & $120 \mathrm{~N}+\mathrm{DCD}$ & $23.0^{\mathrm{abA}}$ & 3.5 & $35.5^{\mathrm{aBC}}$ & 6.9 & $28.0^{\mathrm{bA}}$ & 4.1 & $7.5^{\mathrm{aB}}$ & 3.9 \\
\hline & \multirow[t]{2}{*}{2014} & $120 \mathrm{~N}$ & $30.3^{\mathrm{aA}}$ & 1.8 & $68.9^{\mathrm{aA}}$ & 4.2 & $22.0^{\mathrm{aA}}$ & 4.5 & $47.6^{\mathrm{aA}}$ & 4.2 \\
\hline & & $120 \mathrm{~N}+\mathrm{DCD}$ & $29.1^{\mathrm{aA}}$ & 1.8 & $65.0^{\mathrm{aA}}$ & 4.1 & $26.1^{\mathrm{aA}}$ & 4.3 & $38.8^{\mathrm{aA}}$ & 4.0 \\
\hline
\end{tabular}

Values with same lowercase letters are not statistically significantly different for least squares means separately for each year and field $(\alpha=0.05)$. Values with same uppercase letters are not statistically different for least squares means separately for each field $(\alpha=0.05)$. $\mathrm{SE}=$ standard error of least squares means for $\mathrm{N}$ rate effect. $\mathrm{SE}$ of the year and year* $\mathrm{N}$ rate effect are not shown in the table 
the chamber for initial temperature determination. After a settling time of $15 \mathrm{~min}$ four gas samples $(0,10,20$ and 30 min after chamber placement on the ring) were taken per chamber. Samples were taken with a syringe $(5 \mathrm{ml})$ through the septum on the top of the chamber. In 2013, the first gas sampling took place 4 days after the second $\mathrm{N}$ split application in the main and DCD sub-plots (18 DAS), while second gas sampling was at 45 DAS, 4 days after the last $\mathrm{N}$ split application. For the second maize crop season (2014), the methodology was slightly adjusted due to practical and financial constraints. Gas emission was measured after the last $\mathrm{N}$ split (41 DAS) at 43 DAS, 45 DAS and 48 DAS in the main and DCD sub-plots of the 0 and $240 \mathrm{~N}$ treatments.

$\mathrm{N}_{2} \mathrm{O}$ flux was calculated according to:

$$
F_{N}=k_{N 2 O}(T 0 / T 1)(V / A)(d c / d t)
$$

where $F_{N}$ is the flux of $\mathrm{N}-\mathrm{N}_{2} \mathrm{O}$ in $\mu \mathrm{g} \mathrm{m}^{-2} \mathrm{~h}^{-1}$, $T_{0}=273 \mathrm{~K}, T_{1}=$ initial temperature in the chamber in $\mathrm{K}, V=$ volume in $\mathrm{m}^{3}$ of the chamber, $A=$ chamber area in $\mathrm{m}^{2}, d c$ the slope across the four $\mathrm{N}_{2} \mathrm{O}$ measurements per chamber in ppm $\mathrm{N}_{2} \mathrm{O}$ and $d t=$ slope of measurement intervals in h. Factor $k_{N 20}\left(1.25 \mu \mathrm{g} \mathrm{N} \mu \mathrm{l}^{-1}\right)$ was used to convert $\mathrm{N}_{2} \mathrm{O}$ in ppm to $\mu \mathrm{g} \mathrm{N}-\mathrm{N}_{2} \mathrm{O} \mu \mathrm{l}^{-1}$.

\section{Statistical analysis}

For statistical analysis, the SAS version 9.4 (SAS Institute Inc., Cary, NC, USA) was used. For intra-field data analysis a linear model with effects for blocks, $\mathrm{N}$ fertilizer rates, +/-DCD application and seasons (2013 or 2014) was fitted for within-trial data analysis using the GLIMMIX procedure. Studentized residuals were inspected graphically for normality and homogeneity. Factors or interactions among factors being not significant for $\alpha=0.05$ were removed from the model. Means of factors found significant in the type-III $F$-test (when $p$-value $<0.05$ ) for the respective model were compared by using the LINES option in the LSMEANS statement. Precise $p$-values are presented to point out to differences in terms of significance among treatments below the cutoff level ( $p=0.05)$. In order to account for pre-treatment field differences, mineral $\mathrm{N}$ results were partially expressed in relation to soil organic $\mathrm{N}$ content. For inter-field data analysis of not replicated pre-culture effects (Bh or $\mathrm{M}$ ) we abstained from use of an adjusted (fixed effect) model but used simple plot $t$-tests for selected parameters without directly inferring a causal relationship. Due to this limitation, we included additional controls (e.g. +/- DCD) in the intra-field trials to assess BNI effects.

\section{Results}

Soil incubations

Laboratory incubation of soils collected before sowing maize in the first season (2013) after Bh revealed significant lower evolving $\mathrm{NO}_{3}{ }^{-}$values during the incubation period compared to soils from the non BNI field $\mathrm{M}$ (Fig. 2). The incubation results demonstrated also an efficient nitrification inhibition by the applied SNI (DCD). Additionally, nitrification inhibition with DCD was not significantly different from the BNI effect. Net mineralization was significantly higher for $\mathrm{M}$ compared to $\mathrm{M}+\mathrm{DCD}$ or Bh. During the incubation M showed minor changes in terms of $\mathrm{NH}_{4}{ }^{+}$mineralization, but decreasing $\mathrm{N}-\mathrm{NH}_{4}{ }^{+}$values under BNI $(\mathrm{Bh})$ and $\mathrm{SNI}(\mathrm{M}+\mathrm{DCD})$ suggested a strong immobilization of applied mineral $\mathrm{N}$ in the soil in 2013. In contrast, soil incubations before maize sowing in 2014 showed similarly high nitrification activity in soils from Bh and M (Fig. 2). As already observed in 2013, the application of DCD in 2014 to both Bh and M reduced nitrification activity severely.

In 2013, field $\mathrm{NO}_{3}{ }^{-}$values in topsoil at 42 DAS (Table 2) one day before the third $\mathrm{N}$ split fertilizer application and at the end of the vegetative phase (82 DAS) were low in both fields with no major significant residual effect to previous applications of N or DCD. Comparison of the 2 sampling dates within each field indicated higher $\mathrm{NO}_{3}{ }^{-}$values at 82 DAS compared to $42 \mathrm{DAS}$ for $\mathrm{Bh}$ $(p=0.0012)$ whereas this was not significant for the $\mathrm{M}$ field $(p=0.1488)$. In 2014, both soil mineral $\mathrm{N}$ forms were measured but only in the two most contrasting $\mathrm{N}$ rate treatments. At 32 DAS no significant $\mathrm{N}$ fertilization effect on the $\mathrm{N}$ form or quantities in the topsoil were observed. However, 3 weeks after third and last $\mathrm{N}$ dressing (66 DAS) Bh topsoil was significantly higher in $\mathrm{N}^{-\mathrm{NH}_{4}}{ }^{+}$compared to $\mathrm{N}^{-\mathrm{NO}_{3}}{ }^{-}(p=0.0027)$ whereas this could not be observed for M treatment ( $p=0.1866$ ) (data not shown).

Maize yields in first cropping season, 2013

Maize grain yields from plots established after the previous $\mathrm{Bh}$ pasture did not differ among $0 \mathrm{~N}$ and $60 \mathrm{~N}$ (Fig. 3a). In contrast, a yield increase of more than 10 
times $(p=0.0012)$ was observed in the $\mathrm{M}$ field between yields of the $0 \mathrm{~N}$ treatment with $215 \mathrm{~kg}$ maize grain and $2226 \mathrm{~kg}$ maize grains at $60 \mathrm{~N}$ (Fig. 3b). Further $\mathrm{N}$ application above $60 \mathrm{~kg} \mathrm{~N} \mathrm{ha}^{-1}$ did not result in higher yields in both fields, but yields after Bh were higher than the control. Plants in DCD sub-plots showed lower grain yields in Bh at 60 and $120 \mathrm{~N}$ compared to DCD free Bh. However, this was not observed for the higher $\mathrm{N}$ levels in both fields. Maize yields were always higher for Bh than in the $\mathrm{M}$ field for all respective $\mathrm{N}$ and DCD treatments.

The agronomic $\mathrm{N}$ use efficiency (ANUE) in plots after the previous pasture (Fig. 3c, d) outperformed those in the continuous maize field with ANUE of $85 \mathrm{~kg}$ grain $/ \mathrm{kg} \mathrm{N}$ fertilizer and $37 \mathrm{~kg}$ grain $/ \mathrm{kg} \mathrm{N}$ fertilizer, respectively when $60 \mathrm{~kg} \mathrm{~N} / \mathrm{ha}$ was applied. ANUE decreased with rising N fertilizer amounts in $\mathrm{Bh}(p<0.0001)$ and $\mathrm{M}(p=0.0023)$ from 60 to $120 \mathrm{~N}$ and was significantly lower for the DCD treatment at $60 \mathrm{~N}$ but not for $120 \mathrm{~N}$ and $240 \mathrm{~N}$.

Maize yields in second cropping season, 2014

In the second cropping season, a clear yield response (Fig. 4a, b) to rising $\mathrm{N}$ supply rates was observed in the main plots at both field sites up to a threshold of $120 \mathrm{~kg}$ $\mathrm{N}$ ha ${ }^{-1}$, but $\mathrm{N}$ fertilization was of less importance to yield formation in $\mathrm{Bh}(p=0.0082)$ compared to $\mathrm{M}$ control $(p<0.0001)$. Under both pre-crop treatments, DCD resulted in lower yields compared to respective $\mathrm{N}$ fertilizer levels. A $t$-test on same $\mathrm{N}$ fertilizer levels and DCD treatments suggested only for $0 \mathrm{~N}$ significant higher yields for Bh compared to $\mathrm{M}$.

The ANUE (Fig. 4c, d) showed smaller differences among $\mathrm{Bh}$ and $\mathrm{M}$ than in 2013. Increasing $\mathrm{N}$ rates reduced ANUE stronger in $\mathrm{M}(p=0.003)$ than in $\mathrm{Bh}(p=0.0112)$. DCD application resulted in lower ANUE in Bh at $60 \mathrm{~N}$ and $120 \mathrm{~N}$ compared to non DCD plots whereas in M this was confirmed for low $\mathrm{N}$ comparison $(60 \mathrm{~N})$ only.

When ANUE in the first and second season were compared, higher ANUE was found in Bh in 2013 at $60 \mathrm{~N}$ and all + DCD treatments, but not for fertilization at 120 and $240 \mathrm{~N}$. In the control field M the trend was the opposite compared to Bh: generally higher ANUE in 2014 compared to the first season, except at $60 \mathrm{~N}$ and $120 \mathrm{~N}+\mathrm{DCD}$.

${ }^{15} \mathrm{~N}$ recovery in maize plants and soil profile

In 2013 under low $\mathrm{N}$ fertilizer rates $(60 \mathrm{~kg} \mathrm{~N})$ an average of $12.0 \%$ of applied ${ }^{15} \mathrm{~N}$ was recovered in plant parts in
$\mathrm{M}$ plots compared to a not significant higher plant $\mathrm{N}$ recovery of $18.2 \%$ in $\mathrm{Bh}$ (Fig. 5). Application of $120 \mathrm{~kg}$ $\mathrm{N} \mathrm{ha}^{-1}$ showed as well no difference in plant ${ }^{15} \mathrm{~N}$ recovery between $\mathrm{M}(26.2 \%)$ and $\mathrm{Bh}(23.6 \%)$. In $\mathrm{M}$, plant ${ }^{15} \mathrm{~N}$ recovery was increased at $120 \mathrm{~N}$ compared to $60 \mathrm{~N}$, but DCD had no significant effect on plant $\mathrm{N}$ recovery at the same $\mathrm{N}$ fertilizer level.

In 2014 plant ${ }^{15} \mathrm{~N}$ recovery values at $120 \mathrm{~N}$ were above $30 \%$ in both fields, however, they were not significantly higher than in the respective treatments in 2013. As in 2013, DCD did not significantly increase plant $\mathrm{N}$ recovery either. Overall, soil ${ }^{15} \mathrm{~N}$ recovery was not affected significantly by $\mathrm{N}$ rate, DCD or the interaction of both ( $\mathrm{N}$ rate* $\mathrm{DCD}$ ) within the respective fields and seasons. Total soil ${ }^{15} \mathrm{~N}$ recovery in 2014 for $\mathrm{Bh}$ ranged between $42.0 \%(120 \mathrm{~N})$ and $48.6 \%(120 \mathrm{~N}+$ DCD) being statistically similar to $\mathrm{M}$ values of $46.9 \%$ at $120 \mathrm{~N}$ and $37.8 \%$ at $120 \mathrm{~N}+\mathrm{DCD}$.

In both cropping seasons, most of the detected ${ }^{15} \mathrm{~N}$ within the soil profile was still found in the topsoil layer 0-10 cm (Fig. 6). No consistent significant treatments effects on depth movement were found. However, apparently DCD application decreased the relative ${ }^{15} \mathrm{~N}$ recovery in the subsoil $(0-60 \mathrm{~cm})$ in both fields in 2013 , indicated by a ${ }^{15} \mathrm{~N}$ topsoil:subsoil recovery ratio for $\mathrm{Bh}(p=0.054)$ of $2.9(\mathrm{Bh} 120 \mathrm{~N})$ and $5.0(\mathrm{Bh}$ $120 \mathrm{~N}+\mathrm{DCD})$ and $2.1(\mathrm{M} 120 \mathrm{~N})$ and $4.6(\mathrm{M}$ $120 \mathrm{~N}+\mathrm{DCD})(p=0.674)$. However, this pattern was not confirmed in the second season.

Unaccounted $\mathrm{N}$ losses (Fig. 5) in 2013 for Bh varied between $45.1 \%(120 \mathrm{~N})$ and $48.3 \%(120 \mathrm{~N}+\mathrm{DCD})$ compared to $44.8 \%$ and $46.7 \%$ for $\mathrm{M}$ in the respective $\mathrm{N}$ treatments (Fig. 5). In Bh micro-plots $\mathrm{N}$ losses were not affected by the fertilizer rate or DCD application or its interaction $(\mathrm{N}$ rate*DCD). Furthermore, the cropping season effect was significant $(p=0.0224)$ for Bh. $\mathrm{N}$ loss comparison among the fields on the same $\mathrm{N}$ levels showed no significant ( $t$-test) difference in terms of lost $\mathrm{N}$ amounts in both seasons.

In both years, $\mathrm{Bh}$ showed higher total plant $\mathrm{N}$ yields compared to $\mathrm{M}$ (Table 3) being expressed more strongly in the first season after Bh pasture conversion. Within Bh plant $\mathrm{N}$ uptake was not significantly affected by $\mathrm{N}$ rate, DCD, year or its interaction. Maize cultivated on the previous pasture field (Bh) took up higher amounts of $\mathrm{N}$ from the soil in 2013 than from applied fertilizer $\mathrm{N}$ $(p<0.0001)$, however not in $2014(p=0.6298)$. The opposite was observed for maize in the control field (M) in 2013 , i.e. $\mathrm{N}$ uptake from the fertilizer was higher 
$(p=0.0093)$ compared to soil $\mathrm{N}$ uptake when $\mathrm{N}$ rate was $120 \mathrm{~N}$ (+/- DCD) in the first season, whereas in 2014 it was vice versa.

Nitrous oxide emission

Nitrous oxide emissions $\left(\mathrm{N}_{2} \mathrm{O}\right)$ in the first maize season (2013) showed no significant $\mathrm{N}$ rate, DCD or $\mathrm{N}$ rate*DCD effect for both fields but large differences among the three field plot replications (Table 2). Interfield analysis via $t$-test indicated significantly lower $\mathrm{N}_{2} \mathrm{O}$ emissions in $\mathrm{M}$ than in $\mathrm{Bh}$ for some $\mathrm{N}$ rates or $+/-$ DCD treatments, but a clear trend was absent. During the second cropping season (2014) after pasture conversion $\mathrm{N}_{2} \mathrm{O}$ flux values were not significantly different than in 2013, due to the observed large variability. $\mathrm{N}$ fertilizer application increased $\mathrm{N}_{2} \mathrm{O}$ emissions particularly at the third sampling date in 2014 (7 days after $\mathrm{N}$ fertilization, 48 DAS) for M $(p=0.0432)$. However, at the same time $\mathrm{N}_{2} \mathrm{O}$ emissions were decreased when DCD was applied together with $240 \mathrm{~N}$ being significant for $\mathrm{M}$. The pattern looked similar for Bh although effects on emissions were not significant. The control $(0 \mathrm{~N})$ showed low $\mathrm{N}_{2} \mathrm{O}$ emissions in both fields at all 3 sampling dates indicating that the observed increase in $\mathrm{N}_{2} \mathrm{O}$ emissions under $240 \mathrm{~N}$ was due to $\mathrm{N}$ fertilization. The comparison of the trials $\mathrm{Bh}$ and $\mathrm{M}$ via $t$-test indicated no significant differences in $\mathrm{N}_{2} \mathrm{O}$ emissions among the fields in 2014.

\section{Discussion}

Residual effect of Bh on maize crop performance

The hypothesis that the previous Bh CIAT 679 pasture has a positive effect on maize growth could be confirmed. Even when no $\mathrm{N}$ fertilizer was applied grain yields kept up with the commonly found range of 3.0 $4.5 \mathrm{t} \mathrm{ha}^{-1}$ for the Colombian Eastern Plains (Thomas et al. 2004). This is in line with observations by Moreta et al. (2014), who showed higher maize grain yields on a previous $\mathrm{Bh}$ pasture field compared to those on a previous maize-soybean rotation or on a converted native savanna field. Long-term pasture use (Bh) was likely to have enhanced the soil organic matter content compared to the control (M) field. Furthermore, the shift from pasture to crop could have had positive effects in terms of reduced pests and diseases as known from field research in the Brazilian Cerrados (Lopes et al. 2004). As shown by Fisher et al. (1994) and Amézquita et al. (2004), improved pastures of Bh can have positive effects on soil physical, chemical and biological properties. An estimated amount of root $\mathrm{N}$ of $18 \mathrm{~kg} \mathrm{ha}^{-1}$ in Brachiaria pastures has been reported (Rao 1998), and is likely to even increase under well managed long-term pasture use as found by De Oliveira et al. (2004). Decomposition studies with litter bags have shown that even 140 days after incorporation $40 \%$ of nutrients can remain in the soil in the form of $\mathrm{Bh}$ litter (Thomas and Asakawa 1993), whereas the half-life (in terms of $\mathrm{N}$ release) for maize residues has been documented between only 43-35 days (Thomas et al. 2004). Therefore, it is suggested that mineralized $\mathrm{N}$ from enhanced organic matter contributed to the observed improved crop nutrition of the subsequent maize crop in the first season of the present study. Furthermore, the importance of additional fertilizer $\mathrm{N}$ on maize yield formation was higher for $\mathrm{M}$ than for $\mathrm{Bh}$, which relied to a larger extent on $\mathrm{N}$ derived from soil. ANUE results further supported the beneficial effect of the long-term Bh pasture. However, Basamba et al. (2006) reported lower yields under no- and minimum tilled Colombian savanna Oxisols in the following maize cropping seasons compared to a maize monoculture, suggesting that converting (no BNI) native grassland into arable land does not necessarily result in a positive yield increase of the subsequent crop. Furthermore, an experiment in 1989 showed that upland rice yields were significantly higher after a 10 year old Brachiaria decumbens (Bd) pasture compared to rice after the conversion of a savanna, even when no N was applied (Sanz et al. 2004). This is analog to the observation of the present study. However, BNI as additional benefit from $\mathrm{Bd}$ has not been mentioned in the article, although BNI activity has not only been detected in Bh but also in Bd (Subbarao et al. 2007a). Thus, the focus on the combined effect of organic matter dynamics as well as a BNI effect in our field trial on crop performance after Bh pasture use is therefore new and has probably not been studied since the residual BNI of Brachiaria grasses was not yet known or simply ignored.

Evidence of the residual BNI effect

We hypothesized that the BNI effect induced by Brachiaria humidicola will be present in the soil even 
when the pasture has been removed and that this has a positive effect on the succeeding maize crop. Residual BNI activity was evident in reduced nitrification in soil from the previous $\mathrm{Bh}$ pasture in 2013 in the incubation study. This is in line with similar early observations by Sylvester-Bradley et al. (1988), Ishikawa et al. (2003) and Subbarao et al. (2006a, 2007a) who also found lower nitrification in terms of low $\mathrm{NO}_{3}{ }^{-}$values over time and stable $\mathrm{NH}_{4}{ }^{+}$values under existing $\mathrm{Bh}$ pastures. In terms of soil incubation effects, however, two processes might operate simultaneously, i.e. a net substance effect (exudates or extracts from plant tissues applied to soil) as well as a residual fine root effect influencing $\mathrm{N}$ dynamics through $\mathrm{N}$ mineralization and immobilization (Purchase 1974). According to Robertson and Groffman (2015), microbial nitrifiers are rather weak competitors for available $\mathrm{NH}_{4}{ }^{+}$, and nitrification accelerates when $\mathrm{NH}_{4}{ }^{+}$supply exceeds the demand of the plants. Organic matter with a high $\mathrm{C}: \mathrm{N}$ ratio causes microbial immobilization (Urquiaga et al. 1998; Sakala et al. 2000), and Thomas and Asakawa (1993) documented C:N ratios of Bh litter within a range of $89-160$. However, immobilization and consequently substrate shortage was also observed in the control soil (M) since maize roots and maize stover as well have high C:N ratios (Paré et al. 2000), although net nitrification prevailed. Application of DCD to $M$ soil resulted in low nitrification in both incubation studies, and on the other hand confirmed the presence of active BNI effects after Bh. However, the effect might be partly reduced by the accompanied decreasing $\mathrm{NH}_{4}{ }^{+}$, which was probably the consequence of immobilization favored by DCD (Juma and Paul 1983; Clay et al. 1990), since soil microorganisms seem to have a preference for $\mathrm{NH}_{4}{ }^{+}$rather than for $\mathrm{NO}_{3}{ }^{-}$(Recous et al. 1992). Under field conditions, the observed varying $\mathrm{NO}_{3}{ }^{-}$levels in topsoil indicated that nitrification was not consistently or completely inhibited by the residual BNI effect, not even throughout the first cropping season.

Subbarao et al. stated in their review (2006b) that the suppression of nitrification is a potential key strategy to improve $\mathrm{N}$ recovery and ANUE. The present study confirmed that in the first season the residual BNI effect contributed to enhanced $\mathrm{N}$ yields and improved ANUE. Uptake of soil derived $\mathrm{N}$ by the maize crop was higher for $\mathrm{Bh}$ compared to $\mathrm{M}$, a potential consequence of enhanced retention of mineralized $\mathrm{N}$ and consequently $\mathrm{N}$ nutrition of maize. However, the residual BNI effect was not reflected in higher fertilizer ${ }^{15} \mathrm{~N}$ uptake nor were fertilizer ${ }^{15} \mathrm{~N}$ losses reduced compared to the control site. Our data suggested that applied ${ }^{15} \mathrm{~N}$ was very rapidly immobilized in the topsoil and that maize in the Bh field compensated the low $\mathrm{N}$ availability by taking up mineralized $\mathrm{N}$ from sub-soil layers, which explains the enhanced $\mathrm{N}$ nutrition of maize in the $\mathrm{Bh}$ site.

According to our study, the lack of the residual BNI effect on $\mathrm{N}_{2} \mathrm{O}$ emissions suggests that residual BNI does not necessarily have a similar effect as the in situ pasture BNI effect described by Subbarao et al. (2009) where $\mathrm{N}_{2} \mathrm{O}$ emissions were found to be reduced. It has been shown by Fisher et al. (1994) and Amézquita et al. (2004) that accumulation of $\mathrm{Bh}$ root biomass can vastly enhance soil C. Others reported that denitrification is also spurred by available C substrates (Bergstrom et al. 1994). For the $\mathrm{Bh}$ site enhanced $\mathrm{C}$ availability is expected as indicated by the higher organic matter contents favoring denitrifiers (Firestone and Davidson 1989), that might have masked a sound $\mathrm{N}_{2} \mathrm{O}$ reduction due to residual $\mathrm{BNI}$ in the subsequent maize crop. Due to the high rainfall (i.e. $3685 \mathrm{~mm} /$ year) in the area temporal anaerobic conditions that favor denitrification are expected during and shortly after heavy rainfall despite reasonably good drainage of these Oxisols.

\section{Persistence of BNI}

Generally, turnover of plant residues in humid tropical systems is fast (Urquiaga et al. 1998). Therefore, it was hypothesized that the BNI effect from previously released root exudates or contained within incorporated Bh material would diminish over time. Subbarao et al. (2007a) could show that in soil from 10 year old Bh field plots, including the CIAT 679 accession, inhibited nitrification activity lasted up to 30 days after incubation initiation. After 15 years of pasture use with Bh CIAT 679 we expected a substantial amount of BNI substances in the soil as shown by Subbarao et al. (2008), however a technique to measure these active compounds in the soil has still not been developed. The present study confirmed that nitrification inhibition in soil could be observed until about 6 weeks after removal of Bh. However, a BNI effect before the second cropping season 2014 could not be confirmed in the incubation assay any more. Our results thus suggest that a substantial residual BNI effect on soil processes lasted for less than 1 year. Consequently, it could be speculated 
that BNI inhibitor compounds are exposed to decomposition limiting their persistence in soils. Lower BNI persistence over time was expected since Bh root exudates contain hydrophobic and hydrophilic substances (Ipinmoroti et al. 2008) where the latter are prone to leaching, and furthermore, that several released substances from incorporated Bh litter may attract heterotrophic microbial populations that metabolize C (Lynch and Whipps 1990).

\section{Effect of DCD on maize crop performance}

The synthetic control treatment (DCD) showed no efficient nitrification inhibition in the field in contrast to its efficiency under controlled conditions. Furthermore, no significant beneficial effects of DCD on plant $\mathrm{N}$ recovery, soil $\mathrm{N}$ recovery nor a reduction of ${ }^{15} \mathrm{~N}$ losses in the microplots in the previous Bh pasture could be found in both years, while for $\mathrm{M}$ even significant increased ${ }^{15} \mathrm{~N}$ losses in both years were observed. Regardless of its ability to prevent $\mathrm{N}$ losses from soil DCD in the presented study did not favor crop growth and performance. Losses of the mobile DCD from system with high rainfall have been observed by Amberger (1989). Weiske et al. (2001) could also not confirm a positive DCD effect on maize, but observed lower emission of $\mathrm{N}_{2} \mathrm{O}$ since DCD has been shown to retard nitrification (Prasad et al. 1971) and consequently reduce $\mathrm{NO}_{3}{ }^{-}$as substrate for denitrifiers. Earlier, Clay et al. (1990) reported reduced maize grain yields combined with lower total $\mathrm{N}$ uptake by the crop. According to the reduced $\mathrm{NH}_{4}{ }^{+}$mineralization results in the presented incubation study it is suggested that DCD favors $\mathrm{N}$ immobilization. Such an effect has been observed also by others (Guiraud et al. 1989; Clay et al. 1990; Ernfors et al. 2014) and could have had a negative impact on $\mathrm{N}$ nutrition of the maize plants. Its stability and effectiveness is also known to be negatively affected by high soil temperature (Ruser and Schulz 2015). We thus cannot confirm high effectiveness of DCD in the field, like others, e.g. Merino et al. (2001) who found no $\mathrm{N}_{2} \mathrm{O}$ reduction in a DCD treated and mineral fertilized grassland soil in Northern Spain.

\section{Conclusions}

This is the first in depth study on the potential residual $\mathrm{BNI}$ effect of $\mathrm{Bh}$ on a following maize cropping system. The residual effect of the long-term Bh pasture increased maize grain yields in the first season under all evaluated $\mathrm{N}$ fertilizer rates and in the second season after pasture conversion for the treatment without $\mathrm{N}$ fertilizer compared to arable land. This was associated with a higher total $\mathrm{N}$ uptake under the previous $\mathrm{Bh}$ pasture compared to $\mathrm{M}$ as well as significant reduced nitrification in incubated soils under Bh confirming a residual BNI effect. The study further suggested that applied $\mathrm{N}$ was partially immobilized due to large amounts of incorporated $\mathrm{Bh}$ roots during conversion with a high $\mathrm{C}: \mathrm{N}$ ratio; and $\mathrm{N}$ was subsequently slowly re-mineralized and consequently contributed to maize $\mathrm{N}$ nutrition. Hence, maize performance in $\mathrm{Bh}$ depended less on fertilizer $\mathrm{N}$ compared to the control field $\mathrm{M}$. The contribution of applied $\mathrm{N}$ to yield formation increased in the second season due to a diminished influence of the $\mathrm{Bh}$ residues. Mineral $\mathrm{N}$ in topsoil was not significantly influenced by the amount of $\mathrm{N}$ fertilizer a few days after final $\mathrm{N}$ dressing in 2013 that supports the strong immobilization observed in vitro. At a later stage increased amounts of available $\mathrm{N}_{-} \mathrm{NO}_{3}{ }^{-}$were visible being a good indication for the superior plant growth and grain production in the BNI field however also a possible reduced residual BNI effect in the topsoil at 120 days after $\mathrm{Bh}$ incorporation.

It was challenging to identify the net residual BNI effect of the previous $\mathrm{Bh}$ pasture due to interactions with decomposing Bh plant material. Thus, parallel processes interact where previously released BNI substances from $\mathrm{Bh}$ inhibit or retard nitrification while decomposition is accompanied by a mineralization and green manure effect, that provides $\mathrm{NH}_{4}{ }^{+}$as substrate for nitrifiers and the immobilization effect due to a high $\mathrm{C}: \mathrm{N}$ ratio that can indirectly decrease nitrification. Furthermore, the link between $\mathrm{BNI}$ and $\mathrm{N}_{2} \mathrm{O}$ emission seems not to be clear yet and more frequent sampling might capture the peak of $\mathrm{N}_{2} \mathrm{O}$ emission and identify a possible positive effect due to residual BNI. As control to BNI in the field DCD turned out to lose its nitrification inhibition effect too fast under these humid tropical conditions and therefore alternative substances (DMPP) should be considered for further testing.

Generally N losses from extensively managed pasture systems are low even when $\mathrm{N}$ is supplied to fight degradation of the grassland over time. BNI could therefore play a more important role in terms of its residual effect for subsequent crops under high $\mathrm{N}$ fertilization compared to possible $\mathrm{N}$ loss reduction under present $\mathrm{Bh}$ pastures. Therefore, it is suggested to investigate further mechanism and persistence of a residual BNI effect and its influence on soil $\mathrm{N}$ dynamics in field studies. 
Acknowledgements The authors would like to thank the following people for assistance in the field and laboratory at CIAT and Corpoica in Colombia: Ashly Arevalo, Gonzalo Borrero, Pedro Herrera, Yeisson Herrera, Hernan Mina, Edwin Palma, Oscar Pardo, Paola Pardo, Mauricio Sotelo, Daniel Vergara and Aracely Vidal. For support in Hohenheim the authors are thankful to Sahira Vásquez Báez and Ana María García Hoyos. Thanks to Elke Dachtler and Christian Brandt for the support at the IRMS. For assisting in the interpretation of the GHG data we are grateful to Ivan Guzman-Bustamante and Rong Lang. Furthermore we would like to thank Filippo Cappezone for support with the statistical data analysis.

We very much appreciate the financial support of the project "Climate-smart crop-livestock systems for smallholders in the tropics: Integration of new forage hybrids to intensify agriculture and to mitigate climate change through regulation of nitrification in soil" by the Federal Ministry for Economic Cooperation and Development (BMZ, Germany). This work was done as part of the CGIAR research program on livestock and fish. We thank all donors that globally support the work of the program through their contributions to the CGIAR system.

Open Access This article is distributed under the terms of the Creative Commons Attribution 4.0 International License (http:// creativecommons.org/licenses/by/4.0/), which permits unrestricted use, distribution, and reproduction in any medium, provided you give appropriate credit to the original author(s) and the source, provide a link to the Creative Commons license, and indicate if changes were made.

\section{References}

Amberger A (1989) Research on dicyandiamide as a nitrification inhibitor and future outlook. Commun Soil Sci Plant Anal 20: 1933-1955

Amézquita E, Thomas R, Rao I, Molina D, Hoyos P (2004) Use of deep-rooted tropical pastures to build-up an arable layer through improved soil properties of an Oxisol in the Eastern Plains (Llanos Orientales) of Colombia. Agric Ecosyst Environ 103:269-277

Baligar V, Fageria N, He Z (2001) Nutrient use efficiency in plants. Commun Soil Sci Plant Anal 32:921-950

Basamba T, Barrios E, Amézquita E, Rao I, Singh B (2006) Tillage effects on maize yield in a Colombian savanna oxisol: soil organic matter and P fractions. Soil Tillage Res 91:131-142

Bergstrom D, Tenuta M, Beauchamp E (1994) Increase in nitrous oxide production in soil induced by ammonium and organic carbon. Biol Fertil Soils 18:1-6

Boddey RM, Rao IM, Thomas RJ (1996) Nutrient cycling and environmental impact of Brachiaria pastures. In: Miles JW, Maass BL, do Valle CB (eds) Brachiaria: biology, agronomy, and improvement, vol 259. Centro Internacional de Agricultura Tropical (CIAT), Cali, pp 72-86

Boudsocq S, Niboyet A, Lata JC, Raynaud X, Loeuille N, Mathieu J, Blouin M, Abbadie L, Barot S (2012) Plant preference for ammonium versus nitrate: a neglected determinant of ecosystem functioning? Am Nat 180:60-69
Clay D, Malzer G, Anderson J (1990) Tillage and dicyandiamide influence on nitrogen fertilizer immobilization, remineralization, and utilization by maize (Zea mays L.) Biol Fertil Soils 9:220-225

De Oliveira O, De Oliveira I, Alves B, Urquiaga S, Boddey R (2004) Chemical and biological indicators of decline/ degradation of Brachiaria pastures in the Brazilian Cerrado. Agric Ecosyst Environ 103:289-300

Ernfors M, Brennan FP, Richards KG, McGeough KL, Griffiths BS, Laughlin RJ, Watson CJ, Philippot L, Grant J, Minet EP, Moynihan E, Müller C (2014) The nitrification inhibitor dicyandiamide increases mineralization-immobilization turnover in slurry-amended grassland soil. J Agron Sci 152: $137-149$

Fillery IR (2007) Plant-based manipulation of nitrification in soil: a new approach to managing N loss? Plant Soil 294:1-4

Firestone MK, Davidson EA (1989) Microbiological basis of NO and $\mathrm{N}_{2} \mathrm{O}$ production and consumption in soil. In: Andreae MO, Schimel DS (eds) Exchange of trace gases between terrestrial ecosystems and the atmosphere. John Wiley and Sons, Chichester, pp 7-22

Fisher MJ, Rao I, Ayarza MA, Lascano CE, Sanz J, Thomas RJ, Vera RR (1994) Carbon storage by introduced deep-rooted grasses in the South American savannas. Nature 371:236238

Francis D, Schepers J, Vigil M (1993) Post-anthesis nitrogen loss from corn. Agron J 85:659-663

Gopalakrishnan S, Watanabe T, Pearse SJ, Ito O, Hossain ZA, Subbarao GV (2009) Biological nitrification inhibition by Brachiaria humidicola roots varies with soil type and inhibits nitrifying bacteria, but not other major soil microorganisms. Soil Sci Plant Nutr 55:725-733

Guiraud G, Marol C, Thibaud MC (1989) Mineralization of nitrogen in the presence of a nitrification inhibitor. Soil Biol Biochem 21:29-34

Hilton B, Fixen P, Woodard H (1994) Effects of tillage, nitrogen placement, and wheel compaction on denitrification rates in the corn cycle of a corn-oats rotation. J Plant Nutr 17:13411357

IAEA V (2001) Use of isotope and radiation methods in soil and water management and crop nutrition. Joint FAO/IAEA Division of Nuclear Techniques in Food and Agriculture. Manual Training course series 14, Vienna, Austria

Iizumi T, Mizumoto M, Nakamura K (1998) A bioluminescence assay using Nitrosomonas europaea for rapid and sensitive detection of nitrification inhibitors. Appl Environ Microbiol 64:3656-3662

Ipinmoroti RR, Watanabe T, Ito O (2008) Effect of Brachiaria humidicola root exudates, rhizosphere soils, moisture and temperature regimes on nitrification inhibition in two volcanic ash soils of Japan. World J Agric Sci 4:106-113

Ishikawa T, Subbarao G, Ito O, Okada K (2003) Suppression of nitrification and nitrous oxide emission by the tropical grass Brachiaria humidicola. Plant Soil 255:413-419

Juma N, Paul E (1983) Effect of a nitrification inhibitor on $\mathrm{N}$ immobilization and release of ${ }^{15} \mathrm{~N}$ from nonexchangeable ammonium and microbial biomass. Can J Soil Sci 63:167175

Kluthcouski J, de Oliveira I, Yokoyama L, Dutra L, Portes TDA, da Silva A, Pinheiro BDS, Ferreira E, de Castro EDM, Guimarães CM, Gomide JDC, Balbino LC (2004) The 
Barreirão system: recovering and renewing degraded pastures with annual crops. In: Guimarães EP, Sanz JI, Rao I, Amézquita MC, Amézquita E, Thomas RJ (eds) Agropastoral systems for the tropical savannas of Latin America, vol 338. Centro Internacional de Agricultura Tropical (CIAT), Cali, pp 205-239

Lopes AS, Ayarza M, Thomas RJ (2004) Managing and conserving acid savanna soils for agricultural development: lessons from the Brazilian Cerrados. In: Guimarães EP, Sanz JI, Rao I, Amézquita MC, Amézquita E, Thomas RJ (eds) Agropastoral systems for the tropical savannas of Latin America, vol 338. Centro Internacional de Agricultura Tropical (CIAT), Cali, pp 11-41

Lynch J, Whipps J (1990) Substrate flow in the rhizosphere. Plant Soil 129:1-10

Merino M, Estavillo J, Pinto M, Rodriguez M, Dunabeitia M, González-Murua C (2001) Nitrous oxide emissions from grassland in an intensive dairy farm in the Basque Country of Spain. Soil Use Manag 17:121-127

Miles JW, do WCB V, Rao IM, VPB E (2004) Brachiaria grasses. In: Sollenberger LE, Moser L, Burson B (eds) Warm-season grasses. ASA/CSSA/SSSA, Madison, pp 745-783

Moreta D, Arango J, Sotelo M, Vergara D, Rincón A, Ishitani M, Castro A, Miles J, Peters M, Tohme J, Subbarao G, Rao I (2014) Biological nitrification inhibition (BNI) in Brachiaria pastures: a novel strategy to improve eco-efficiency of croplivestock systems and to mitigate climate change. Trop Grasslands-Forrajes Trop 2:88-91

Paré T, Gregorich E, Nelson S (2000) Mineralization of nitrogen from crop residues and $\mathrm{N}$ recovery by maize inoculated with vesicular-arbuscular mycorrhizal fungi. Plant Soil 218:11-20

Prasad R, Rajale G, Lakhdive B (1971) Nitrification retarders and slow-release nitrogen fertilizers. Adv Agron 23:337-383

Purchase B (1974) Evaluation of the claim that grass root exudates inhibit nitrification. Plant Soil 41:527-539

Rao I (1998) Root distribution and production in native and introduced pastures in the South American savannas. Root demographics and their efficiencies in sustainable agriculture, grasslands and forest ecosystems. Springer, Netherlands, pp 19-41

Rao I, Ishitani M, Miles J, Peters M, Tohme J, Arango J, Moreta D, Lopez H, Castro A, van der Hoek R, Martens S, Hyman G, Tapasco J, Duitama J, Suárez H, Borrero G, Núñez J, Hartmann K, Domínguez M, Sotelo M, Vergara D, La Velle P, Subbarao G, Rincón Á, Plazas C, Mendoza R, Rathjen L, Karwat H, Cadisch G (2014) Climate-smart crop-livestock systems for smallholders in the tropics: Integration of new forage hybrids to intensify agriculture and to mitigate climate change through regulation of nitrification in soil. Trop Grasslands-Forrajes Trop 2:130-132

Raun WR, Johnson GV (1999) Improving nitrogen use efficiency for cereal production. Agron J 91:357-363

Recous S, Machet JM, Mary B (1992) The partitioning of fertilizer-N between soil and crop: comparison of ammonium and nitrate applications. Plant Soil 144:101-111

Robertson G, Groffman P (2015) Nitrogen transformations. In: Paul EA (ed) Soil microbiology, ecology, and biochemistry, 4th edn. Academic Press, Burlington, pp 421-446

Ruser R, Schulz R (2015) The effect of nitrification inhibitors on the nitrous oxide $\left(\mathrm{N}_{2} \mathrm{O}\right)$ release from agricultural soils - a review. J Plant Nutr Soil Sci 178:171-188
Sakala WD, Cadisch G, Giller KE (2000) Interactions between residues of maize and pigeonpea and mineral $\mathrm{N}$ fertilizers during decomposition and $\mathrm{N}$ mineralization. Soil Biol Biochem 32:679-688

Sanz J, Zeigler R, Sarkarung S, Molina D, Rivera M (2004) Improved rice/pasture systems for native savannas and degraded pastures in acid soils of Latin America. In: Guimarães EP, Sanz JI, Rao I, Amézquita MC, Amézquita E, Thomas RJ (eds) Agropastoral systems for the tropical savannas of Latin America, vol 338. Centro Internacional de Agricultura Tropical (CIAT), Caliban, pp 240-252

Schröder J, Neeteson J, Oenema O, Struik P (2000) Does the crop or the soil indicate how to save nitrogen in maize production?: reviewing the state of the art. Field Crops Res 66:151164

Subbarao G, Ishikawa T, Ito O, Nakahara K, Wang H, Berry W (2006a) A bioluminescence assay to detect nitrification inhibitors released from plant roots: a case study with Brachiaria humidicola. Plant Soil 288:101-112

Subbarao G, Ito O, Sahrawat K, Berry W, Nakahara K, Ishikawa T, Watanabe T, Suenaga K, Rondon M, Rao I (2006b) Scope and strategies for regulation of nitrification in agricultural systems - challenges and opportunities. Crit Rev Plant Sci 25:303-335

Subbarao G, Rondon M, Ito O, Ishikawa T, Rao I, Nakahara K, Lascano C, Berry W (2007a) Biological nitrification inhibition (BNI) - is it a widespread phenomenon? Plant Soil 294: 5-18

Subbarao G, Wang H, Ito O, Nakahara K, Berry W (2007b) $\mathrm{NH}_{4}{ }^{+}$ triggers the synthesis and release of biological nitrification inhibition compounds in Brachiaria humidicola roots. Plant Soil 290:245-257

Subbarao G, Nakahara K, Ishikawa T, Yoshihashi T, Ito O, Ono H, Ohnishi-Kameyama M, Yoshida M, Kawano N, Berry W (2008) Free fatty acids from the pasture grass Brachiaria humidicola and one of their methyl esters as inhibitors of nitrification. Plant Soil 313:89-99

Subbarao G, Nakahara K, Hurtado MP, Ono H, Moreta D, Salcedo AF, Yoshihashi A, Ishikawa T, Ishitani M, OhnishiKameyama M, Yoshida M, Rondon M, Rao IM, Lascano CE, Berry WL, Ito O (2009) Evidence for biological nitrification inhibition in Brachiaria pastures. Proc Natl Acad Sci USA 106:17302-17307

Sylvester-Bradley R, Mosquera D, Mendez J (1988) Inhibition of nitrate accumulation in tropical grassland soils: effect of nitrogen fertilization and soil disturbance. J Soil Sci 39: 407-416

Thomas R, Asakawa N (1993) Decomposition of leaf litter from tropical forage grasses and legumes. Soil Biol Biochem 25: 1351-1361

Thomas R, Rondón M, Amézquita E, Ayarza M, Asakawa N, Friesen D (2004) Overcoming soil constraints in Latin American savannas: new approaches and potential trade-offs. In: Guimarães EP, Sanz JI, Rao I, Amézquita MC, Amézquita E, Thomas RJ (eds) Agropastoral systems for the tropical savannas of Latin America, vol 338. Centro Internacional de Agricultura Tropical (CIAT), Caliban, pp 309-325

Urquiaga S, Cadisch G, Alves BJ, Boddey RM, Giller KE (1998) Influence of decomposition of roots of tropical forage species on the availability of soil nitrogen. Soil Biol Biochem 30: 2099-2106 
Weiske A, Benckiser G, Herbert T, Ottow J (2001) Influence of the nitrification inhibitor 3, 4-dimethylpyrazole phosphate (DMPP) in comparison to dicyandiamide (DCD) on nitrous oxide emissions, carbon dioxide fluxes and methane oxidation during 3 years of repeated application in field experiments. Biol Fertil Soils 34:109-117
Zamudio A, Carrascal C, Pulido J, Gallardo E, Ávila M, VargasVera D (2006) Métodos analíticos del laboratorio de suelos. $6^{a}$ edición. Instituto Geográfico Agustín Codazzi, Bogotá

Zerulla W, Barth T, Dressel J, Erhardt K, von Locquenghien KH, Pasda G, Rädle M, Wissemeier A (2001) 3, 4Dimethylpyrazole phosphate (DMPP) - a new nitrification inhibitor for agriculture and horticulture. Biol Fertil Soils 34: 79-84 